\title{
A COMPARISON BETWEEN CONSUMER AND INDUSTRY PERSPECTIVES ON SUSTAINABLE PRACTICES THROUGHOUT THE APPAREL PRODUCT LIFE CYCLE
}

by

Xingqiu Lou

A thesis submitted to the Faculty of the University of Delaware in partial fulfillment of the requirements for the degree of Master of Science in Fashion and Apparel Studies

Summer 2016

(C) 2016 Xingqiu Lou

All Rights Reserved 
ProQuest Number: 10190526

\section{All rights reserved}

INFORMATION TO ALL USERS

The quality of this reproduction is dependent upon the quality of the copy submitted.

In the unlikely event that the author did not send a complete manuscript and there are missing pages, these will be noted. Also, if material had to be removed, a note will indicate the deletion.

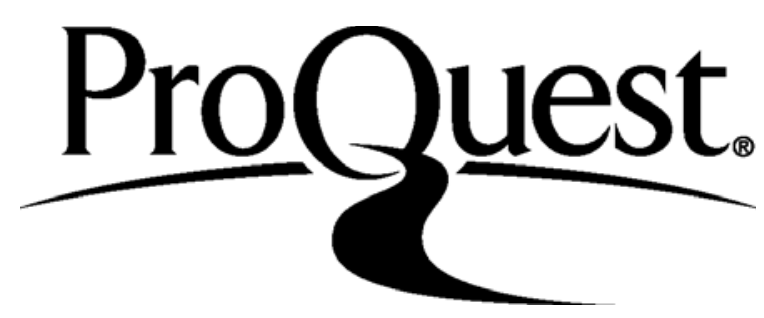

ProQuest 10190526

Published by ProQuest LLC (2016). Copyright of the Dissertation is held by the Author.

All rights reserved.

This work is protected against unauthorized copying under Title 17, United States Code Microform Edition (c) ProQuest LLC.

ProQuest LLC.

789 East Eisenhower Parkway

P.O. Box 1346

Ann Arbor, Ml 48106 - 1346 


\title{
A COMPARISON BETWEEN CONSUMER AND INDUSTRY PERSPECTIVES ON SUSTAINABLE PRACTICES THROUGHOUT THE APPAREL PRODUCT LIFE CYCLE
}

\author{
by \\ Xingqiu Lou
}

Approved:

Huantian Cao, Ph.D.

Professor in charge of thesis on behalf of the Advisory Committee

Approved:

Hye-Shin Kim, Ph.D.

Chair of the Department of Fashion \& Apparel Studies

Approved:

George H. Watson, Ph.D.

Dean of the College of Arts \& Sciences

Approved:

Ann L. Ardis, Ph.D.

Senior Vice Provost for Graduate and Professional Education 


\section{ACKNOWLEDGMENTS}

I would like to express my sincere appreciation and thanks to my advisor and committee chair, Dr. Huantian Cao, for his continuous support of my graduate study

and research, for his patience, motivation, enthusiasm, and profound knowledge. I am extremely appreciative of the substantial time and effort he spent on helping me with the research. Without his kind and patient instruction, it would have been impossible for me to finish this thesis.

Besides my advisor, I would also like to thank my committee members, Dr. Hye-Shin Kim and Dr. Sheng Lu, for their encouragement and insightful comments. Both of them are always glad to participate in the thesis discussion and provide thoughtful feedback on thesis outline, survey design and data analysis.

I would like to express my very profound gratitude to my parents for the support and love they have provided throughout my years of study and the process of writing this thesis. Last but not the least, a very special thanks to my boyfriend, $\mathrm{He}$ Kang, for his unending support and patience over the past two years. This accomplishment would not have been possible without them. 


\section{TABLE OF CONTENTS}

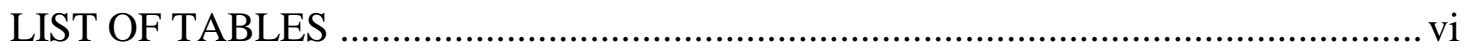

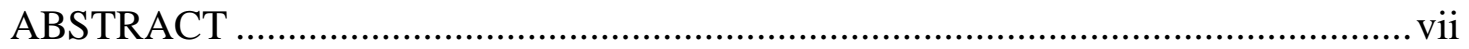

\section{Chapter}

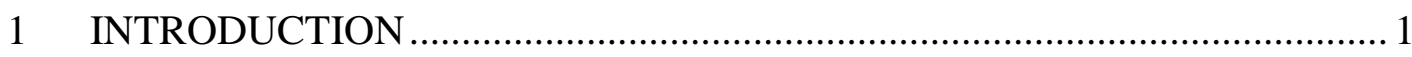

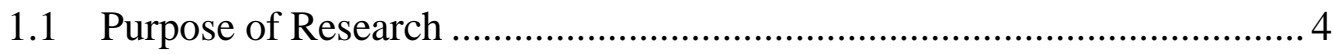

1.2 Research Objectives ........................................................................ 4

1.3 Significance of the Study …………………....................................... 5

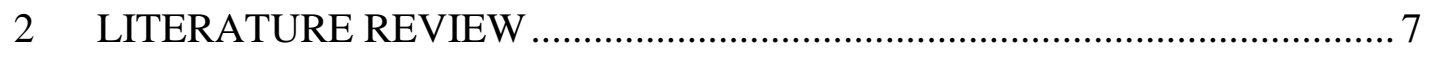

2.1 Sustainability and Environmental Issues in the Apparel Industry............. 7

2.2 Introduction to the Sustainable Apparel Coalition and Higg Index .......... 9

2.3 Comparison between Apparel Industry and Consumers .......................... 12

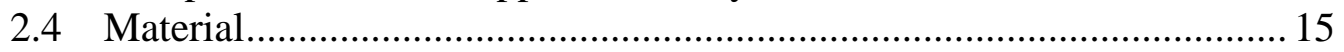

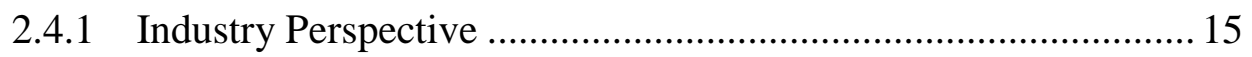

2.4.2 Consumer Perspective …………………………........................ 17

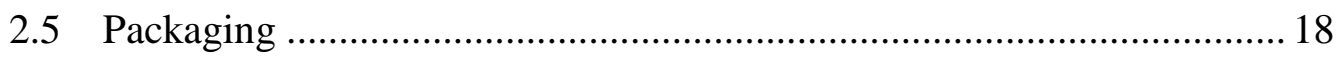

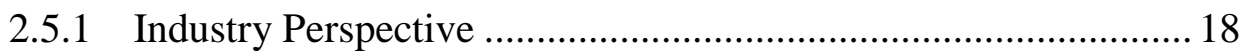

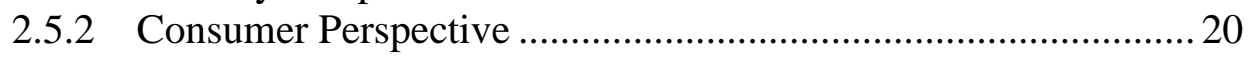

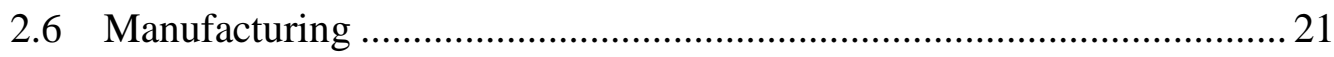

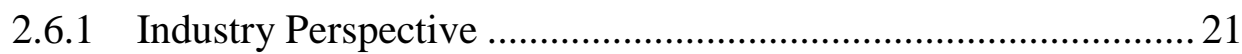

2.6.2 Consumer Perspective .............................................................. 22

2.7 Transportation................................................................................. 23

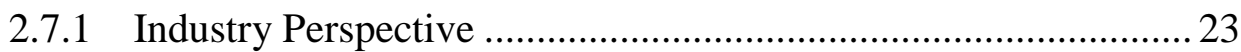

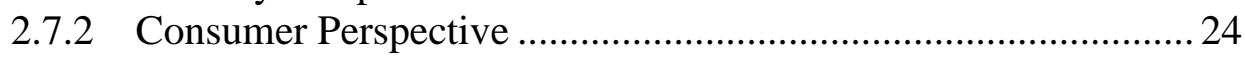

2.8 Product Care \& Repair Service ……………………......................... 25 
2.8.1 Industry Perspective ............................................................ 25

2.8.2 Consumer Perspective ......................................................... 26

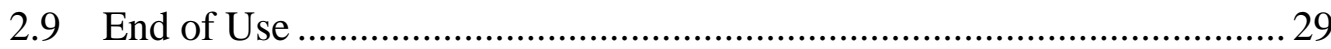

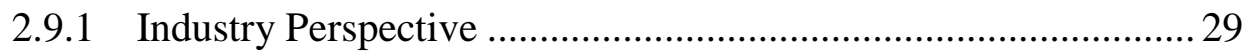

2.9.2 Consumer Perspective ........................................................... 30

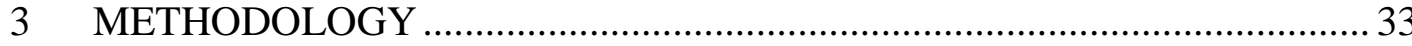

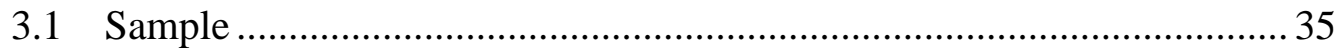

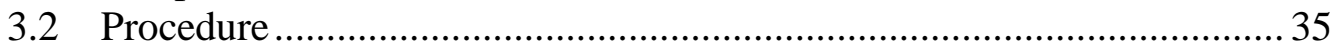

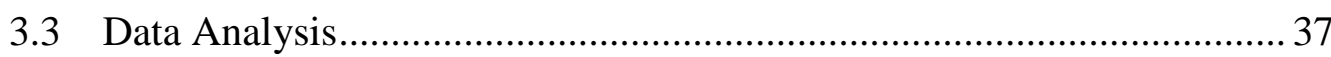

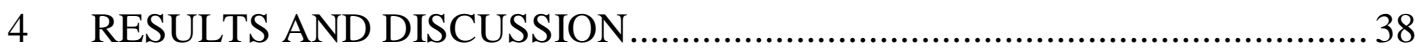

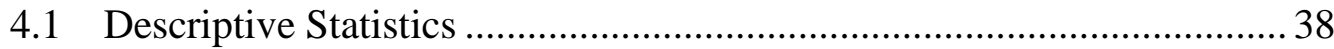

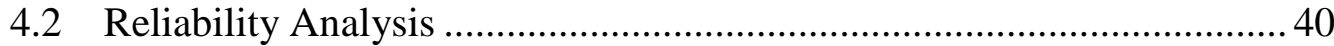

4.3 Comparison between the Perspective of Industry and Consumers ......... 41

4.4 Willingness to Pay .............................................................................. 44

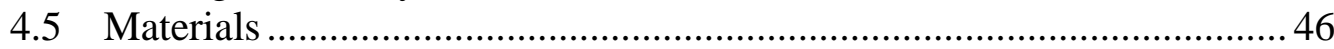

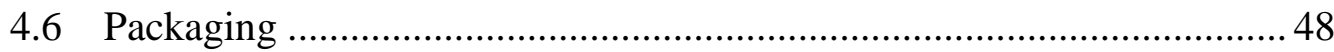

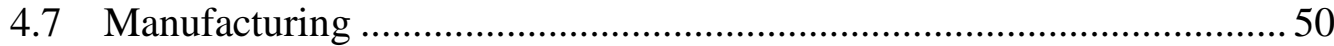

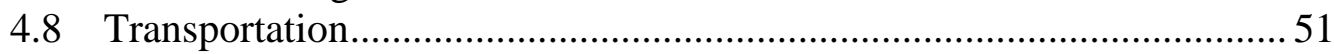

4.9 Product Care and Repair Service..................................................... 53

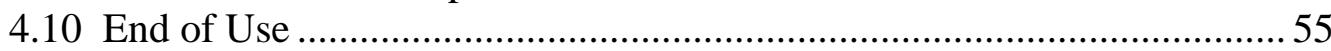

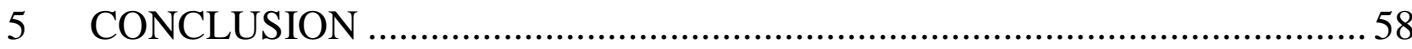

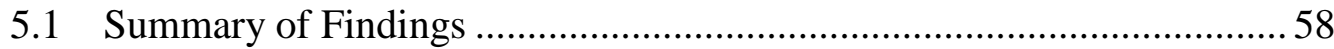

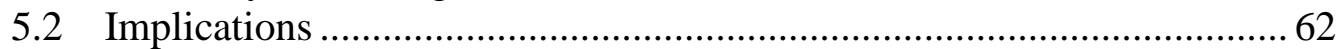

5.3 Limitations and Future Research...................................................... 63

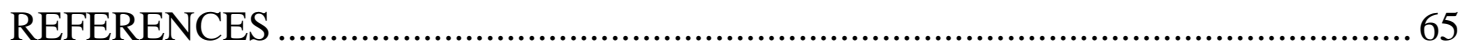

Appendix

A IRB REVIEW AND CONSENT FORM …......................................... 75

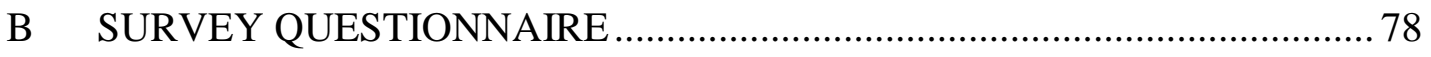




\section{LIST OF TABLES}

Table 2.1 Weight distribution in the Higg Brand Environmental Module................ 12

Table 2.2 Phases of the product life cycle that worry consumers (Niinimäki \& Hassi, 2011) ................................................................................... 13

Table 2.3 Reasons for disposal of clothes in study of 24 Norwegian women

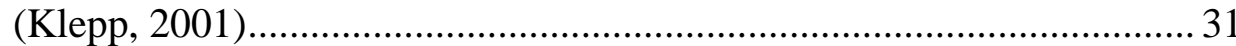

Table 3.1 Objectives and of hypotheses in this research .................................. 33

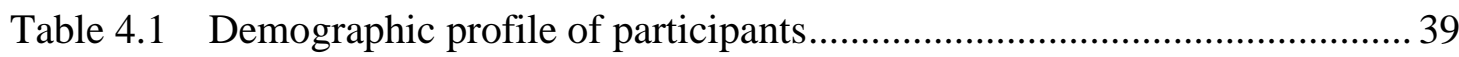

Table 4.2 Descriptive statistics on participants' knowledge .............................. 40

Table 4.3 Reliability test using Cronbach's alpha ........................................... 40

Table 4.4 Comparing consumers' perspective and industries' perspective on different stages of the product life cycle ............................................ 41

Table 4.5 Consumers' willingness to pay on different stages of the product life cycle.

Table 4.6 Chi-square test result for willingness to pay ....................................... 45

Table 4.7 Chi-square test result for material ................................................. 47

Table 4.8 Chi-square test result for packaging ............................................ 48

Table 4.9 Chi-square test result for manufacturing ........................................50

Table 4.10 Chi-square test result for transportation ........................................52

Table 4.11 Chi-square test result for product care and repair service ...................... 53

Table 4.12 Chi-square test result for end of use ........................................... 55

Table 5.1 Results of hypothesis testing ......................................................... 58 


\begin{abstract}
The apparel and textile industry creates a significant environmental footprint at each stage of the product life cycle. As environmental awareness has expanded, different practices have been adopted to reduce the negative impacts on the environment and to maximize the benefits to humans and society. Accordingly, it calls for more discussion on consumer perception towards the apparel industry's sustainable practices. The purpose of this study is to investigate consumer perceptions of the apparel industry's sustainable practices throughout the product life cycle and whether consumers are willing to pay a premium for these practices. The industry's perspective on sustainable practices was obtained from the Higg Index, which is a tool widely used by industry to measure environmental performance throughout the six stages of the product life cycle, i.e., materials, manufacturing, packaging, transportation, product care and repair service, and end of use. An online survey was conducted to collect data on consumer perceptions on different sustainable practices. It was found that the apparel industry and consumers have different perspectives on the importance of sustainable practices in different stages of the apparel product life cycle, as well as within the stage of materials, manufacturing and end of use. Furthermore, consumers' willingness to pay a premium on the apparel industry's sustainable practices does not match with the industry's perspective, as reflected by the Higg Index. This study makes recommendations for reallocating the weight/point distributions for the Higg Index and for revising current sustainable performance for apparel companies.
\end{abstract}




\section{Chapter 1 INTRODUCTION}

Apparel has a long and complex life cycle consisting of various stages from raw material to final disposal (Allwood, Laursen, de Rodriguez \& Bocken, 2006). As one of the most manufacture-intensive industries, the apparel and footwear production impacts the environment at every stage along the product life cycle, including fiber growth and manufacturing, dyeing and finishing, transportation and distribution, washing and drying, and ultimate disposal (Fletcher, 2008; Fulton \& Lee, 2010). Particularly, the major environmental impacts include the extensive use of energy and toxic chemicals, greenhouse gas emission, wastewater effluent and solid waste output (Allwood et al., 2006).

As awareness of the environmental issues in the apparel and textile industry has expanded, stakeholders have developed various tools for measuring environmental impacts throughout the product life cycle (Kozar \& Connell, 2015). The Higg Index is one of the leading tools developed by the Sustainable Apparel Coalition (SAC). Used by more than 150 different companies, the Higg Index is aimed at measuring and improving the environmental and social labor impacts of apparel and footwear products. The Higg Index is comprised of three different modules: Brand, Facility and Product. Each module involves both environment and social responsibility parts. These three modules are widely used by both industry and academia. Many apparel companies are currently using the Brand Module and Facility Module to measure the environmental impacts of their apparel and footwear products (Reuben, 2013). 
Moreover, many researchers applied the Product Module to measure the product environmental performance at different stages of the product life cycle (Cao et al., 2015; Khan \& Islam, 2015).

The Higg Brand Environmental Module focuses on helping apparel and footwear brands assess their environmental management policies and practices at each stage of the product life cycle. The Higg Brand Environmental Module includes seven sections: the general section, materials, manufacturing, packaging, transportation, product care and repair service and end of use. The general section covers companies' overall internal environmental management, and the other six sections cover different stages in the product life cycle. Each section of the Higg Brand Environmental Module has 100 points with different weight distribution, and the total maximum points for a company is 100 points.

The increasing awareness of environmental sustainability has led to a growing concern towards apparel companies to minimize the negative impacts on the environment and maximize the benefits to humans and society (Allwood et al., 2015; Khan \& Islam, 2015). Different practices have been adopted in producing sustainable apparel products at different stages throughout the product life cycle (Moon, Youn, Chang \& Yeung, 2013). Many apparel companies have begun producing organic material products during the material selection stage since the conventional cotton production requires the extensive use of toxic chemicals and water (Allwood et al., 2006). Apparel companies such as Patagonia worked with Bluesign® systems to ensure that their products do not contain restricted substances (Romano, 2012). Regarding the packaging of a finished product, apparel companies such as Levi's sold their product in recycled paper packaging in order to reduce the packaging waste (Kim, 
2010). During the manufacturing process, apparel companies have already taken environmental factors into consideration when selecting suppliers and many have their products certified via third parties in order to show their environmentally friendly practices (Subic, Shabani, Hedayati \& Crossin, 2012). When transporting products from factories to the distribution outlets, companies such as H\&M avoided air transportation since it is the most carbon demanding way and they chose marine or rail transport instead (Walker, 2012). The consumer use period is the most energy demanding (Laitala \& Boks, 2012). Levi Strauss \& Co. provided low impact instructions on all global products' care tags (Vestel, 2009), and Patagonia provided step-by-step repair guides and offered repair service to consumers (Becker, 2016). Finally, a large quantity of textile waste ends up in landfills every year (Birtwistle \& Moore, 2007) and many companies are currently developing partnerships with organizations to provide product take-back services.

At the same time, since consumers are increasingly aware of the environmental impacts, sustainable apparel products have become more common and more popular. Accordingly, consumer perceptions regarding sustainable apparel products are always at the center of discussion. The existing consumer studies on sustainability were mostly focused on consumer attitude and behavior regarding organic cotton materials (Ha-Brookshire \& Norum, 2011; Ellis, McCracken \& Skuza, 2012), clothing use phase (Laitala, Klepp \& Boks, 2012; Kruschwitz, Karle, Schmitz \& Stamminger 2014; Ryttinger \& Holtmaat, 2014), and clothing disposal (Birtwistle \& Moore, 2007; Klepp, 2001; Laitala \& Klepp, 2011). However, limited literature has been conducted on consumers' acceptance and evaluation of apparel industries' different sustainable practices throughout the product life cycle. Since the apparel industry has been putting 
lots of efforts for being environmentally friendly, it is important to investigate consumer insight on these sustainable practices.

\subsection{Purpose of Research}

The purpose of this study is to investigate consumer preference of apparel industry's sustainable practices throughout the product life cycle and whether consumers are willing to pay a premium for these practices. The researcher used the Higg Brand Environmental Module to represent the industry's perspective since the Higg Index is widely accepted by the industry as a criterion on sustainable performance in the apparel industry (Reuben, 2013). In the Higg Brand Environmental Module, the general section covers companies' internal environmental management, and the other six sections cover different stages in the product life cycle. Concretely, the Higg Index assigns different weight distribution to each section, representing the apparel industry's perspective on the importance of sustainable practices in different stages of the product life cycle. In addition, several questions are included in each section and every question has its own Higg Index point. Higher point questions indicate that the apparel industry values more toward the related sustainable practices. The researcher conducted an online survey to measure consumer perception on these practices. In other words, this research aims to discover whether there exists a difference between the perspectives of the industry and consumers in regards to environmentally friendly apparel products.

\subsection{Research Objectives}

The objectives of this research are to: 
(1) Identify consumer acceptance of industry's sustainable practices across the product life cycle, including material, manufacturing, packaging, transportation, product care and repair service and end of use.

(2) Identify consumers' willingness to pay a premium on industry's sustainable practices across the product life cycle, including material, manufacturing, packaging, transportation, product care and repair service and end of use.

(3) In each stage of the product life cycle, i.e., material, manufacturing, packaging, transportation, product care and repair service and end of use, identify consumer acceptance of industry's sustainable practices.

\subsection{Significance of the Study}

This study contributes to academia and the apparel industry in twofold. The majority of current consumer research on sustainable apparel products focuses on the relationship between consumer environmental consciousness and purchase behavior (Dembkowski, 1998; Bamberg, 2003; Brosdahl \& Carpenter, 2010), factors that influence sustainable consumption (Chan \& Wong, 2012; Brosdahl \& Carpenter, 2010; Kang, Liu, \& Kim, 2013), and consumers' willingness to pay for sustainable materials (Hustvedt \& Bernard, 2008; Ha-Brookshire \& Norum, 2011; Ellis, McCracken \& Skuza, 2012). However, few studies have been conducted to investigate the relationship between the perceptions of the apparel industry and consumers on different sustainable practices throughout the product life cycle. Therefore, this study attempts to fill this gap.

The results of this study are also significant to apparel companies and provide managerial insights on whether consumers understand and are willing to pay for the sustainable efforts in which apparel companies are currently working. With a better 
understanding of consumer insights, apparel companies would be able to improve and revise their current sustainable performance. In return, these actions would further motivate consumers to purchase environmentally friendly apparel products in the long term. 


\section{Chapter 2}

\section{LITERATURE REVIEW}

\subsection{Sustainability and Environmental Issues in the Apparel Industry}

Apparel has a long and complex life cycle consisting of various stages from raw material to final disposal (Allwood et al., 2006). The clothing life cycle starts with the selection of raw materials. After pre-treatment, the textile fibers are spun into yarns. Then the yarns are woven or knitted into fabrics. After dyed, cut, sewed, trimmed and decorated, the fabric is finally turned into the finished garments. The finished garments are packed and shipped from the production factories to the distribution outlets. The use and maintenance stage happens once consumers purchase the garments and begin wearing them. During the consumer use stage, the garments are washed, dried and ironed. Finally, the garments are discarded when consumers no longer need them (Ryttinger \& Holtmaat, 2014).

The growing popularity in fast fashion, including rapid production, short leadtime and cheap materials, has stimulated consumers to purchase garments at a higher speed. However, cheap fabric and poor garment construction force consumers to discard them shortly, shortening the lifetime of a product (Fletcher, 2010). Furthermore, the apparel and textile industry creates significant environmental and social footprint at each stage of the product life cycle including fiber growth and manufacturing, dyeing and finishing, transportation and distribution, washing and drying, and ultimate disposal (Fulton \& Lee, 2010). The major environmental impacts related to apparel production and utilization include resource depletion from the 
consumption of water, fossil fuels and energy, chemical and greenhouse gas emission, wastewater effluent and solid waste output (Allwood et al., 2006). According to Allwood et al. (2006), conventional cotton products require an extensive use of water and toxic chemicals, which may harm human health and the environment. These chemicals are used in the forms of pesticides and in dyeing, finishing and washing process, and are further released into wastewater, causing water pollution problem and threatening to the lives in these waters (Khan \& Islam, 2015). Also the manufacturing process generates a large amount of solid waste. During the clothing utilization stage, laundering often relates to water consumption and chemical use. Additionally, a large amount of energy is used for drying and ironing. Lastly, the majority of clothing is sent to the landfills instead of being reused or recycled (Goworek, 2011). According to Luz (2007), Americans throw away 68 pounds of clothing and textiles per person per year on average. Similarly, a study conducted by Allwood et al. (2006) revealed that a consumer in the UK throws away on average $30 \mathrm{~kg}$ of clothing and textiles each year. Taking a cotton made T-shirt as an example, a $250 \mathrm{~g}$ cotton $\mathrm{T}$-shirt requires $1.7 \mathrm{~kg}$ fossil fuel for electricity used in washing, drying and ironing, and further causes $4 \mathrm{~kg}$ $\mathrm{CO}_{2}$ emissions. Also, $125 \mathrm{~g}$ of detergent will be released to water during washing the T-shirt, and $450 \mathrm{~g}$ of waste will be sent to the landfills after use (Allwood et al., 2006). According to Yeung and Yeung (2011), the concept of sustainability in the apparel and textile industry is "satisfying the present needs for fashion but without compromising the ability of future generations to meet their own fashion needs." Accordingly, sustainable apparel products are defined as the garments which are designed, manufactured, transported, consumed or recycled with the materials and methods that reflect environmental and social concerns (Meyer, 2001). Different 
practices have been used in producing sustainable apparel products, aimed at minimizing the negative impacts on the environment and maximizing the benefits to humans and society (Moon et al., 2013). In the context of the product life cycle, pursing environmental sustainability in the apparel and textile industry relates to different stages, including raw material selection, manufacturing, utilization, and disposal. Particularly, this may involve a variety of sustainability issues such as the environmental impacts of material selection, the resulted waste during the manufacturing process, how products are produced and packaged, the caused energy use for transportation and how consumers may use and dispose the products (Goworek, 2011). Furthermore, apparel companies, including brands, manufacturers and retailers have been actively devoted to producing and marketing sustainable apparel products to meet the sustainable consumption needs (Fletcher, 2008). For example, Nike created an innovative product, Nike Flyknit, reducing the manufacturing waste and the amount of materials used. This technology has helped Nike reduce nearly 2 million pounds of waste since 2012 (Nike Flyknit, 2015). Patagonia used natural fiber which has a low impact on the environment, and further brought out easy-to-follow repair guides to consumers and offered consumers easy ways to recycle Patagonia products (Becker, 2016).

\subsection{Introduction to the Sustainable Apparel Coalition and Higg Index}

As awareness of the environmental issues in the apparel and textile industry has expanded, stakeholders have developed various tools for measuring environmental impacts throughout the product life cycle (Kozar \& Connell, 2015). The Higg Index is one of the leading tools developed by the Sustainable Apparel Coalition (SAC). Established in 2011, the SAC is an organization consisting of over 150 leading brands, 
retailers, manufacturers, governments, nongovernmental organizations, and academic experts, representing more than one third of the global market shares for apparel and footwear products. The aim of the SAC is to develop a standardized approach for measuring and evaluating apparel and footwear products sustainability performance. The SAC developed the Higg Index, a self-assessment tool for brands, retailers and facilities to measure and improve their environmental and social labor impacts of apparel and footwear products. The index was released on June 26, 2012 as the Higg Index 1.0, and was further upgraded as the Higg Index 2.0 on December 11, 2013. The Higg Index 2.0 is comprised of three different modules: Brand, Facility and Product. Each of these modules can be used independently and each of them results in a numeric index on a scale from 0 to 100 .

Brand, Facility and Product Modules in the Higg Index are widely used by both industry and academia. From a practical aspect, apparel brands such as H\&M, Gap Inc., Nike, Adidas, Puma, Patagonia, Levi Strauss \& Co., and many manufacturers such as DuPont, Advansa, Downlite and Dystar are currently using the Brand Module or Facility Module to measure the environmental impacts of their products (Reuben, 2013). For example, as one of the pioneers of the sustainability initiatives, Levi Strauss \& Co. assessed their current sustainable practices by getting the information through the Higg Index and knew where they need to improve by sharing innovations and best practices with other SAC members. One of India's biggest manufacturers, Arvind, benefited from the Higg Index's Facility Module by establishing an inward chemical-quality tracking policy for chemical management and improving their score in this area from 0 to 60 (Reuben, 2013). From an academic aspect, many researchers used the Product Module to measure the product 
environmental performance at different stages, from initial prototype to sourcing raw materials and to final design. For example, Cao et al. (2015) used the Higg Index to evaluate the environmental performance at each stage of a sustainable automotive employee's uniform and to identify the areas for improvement. Khan and Islam (2015) applied the Higg Index's Product Module to assess the environmental sustainability of material selection and the manufacturing process of a knitted $\mathrm{T}$-shirt made in Bangladesh. Since the Higg Index is a tool primarily created and used by the industry (Reuben, 2013), it is widely accepted by the industry as a criterion on the sustainable performance of apparel and footwear products.

The Higg Index's Brand Module is used by various apparel, footwear and home textiles brands to measure the environmental and social performance of their design, sourcing and operations. The SAC brand members sharing scores and innovative practices with other brands, retailers and facilities transparently, may create new partnerships and lead to a healthy competitiveness around sustainability performance. The Higg Brand Module includes both environmental and social responsibility parts. The environmental part focuses on helping brands assess their environmental management policies and practices at each stage of the product life cycle. The Higg Brand Environmental Module includes seven sections, e.g., the general section, materials, manufacturing, packaging, transportation, product care and repair service, and end of use. Each section has 100 points with different weight distribution, as presented in Table 2.1. Therefore, the total maximum point for a company is 100 points. 
Table 2.1 Weight distribution in the Higg Brand Environmental Module (Summarized from the SAC website, http://apparelcoalition.org)

\begin{tabular}{cc}
\hline Section & Weight \\
\hline General & $15 \%$ \\
Materials & $25 \%$ \\
Packaging & $7.5 \%$ \\
Manufacturing & $20 \%$ \\
Transportation & $7.5 \%$ \\
Product Care \& Repair Service & $15 \%$ \\
End of Use & $10 \%$ \\
Total & $100 \%$ \\
\hline
\end{tabular}

\subsection{Comparison between Apparel Industry and Consumers}

Previous studies have investigated consumer perception on sustainability and environmental issues on different stages during apparel production and consumption. Hill and Lee (2012) conducted research investigating consumers' knowledge on the most and least important sustainable practices in the apparel industry. Regarding the most important sustainable practices, more than half of the participants selected manufacturing related practices such as "energy efficiency" (58.8\%), "fabric waste reduction" (51.3\%) and "water usage control" (50.1\%). Nearly half of the participants chose long-lasting garments (45.1\%) and using recycling packaging material (43.9\%). Relatively few participants listed garments made from sustainable materials such as “organic materials" (11.4\%), "recycled material" (35.2\%), "biodegradable material" $(30.0 \%)$ and "recyclable material" $(35.2 \%)$ as the most important sustainable practices. On the other hand, most of the participants (61.4\%) agreed that laundering and caring information is the least important sustainable practice in the apparel industry (Hill \& Lee, 2012). Similarly, Niinimäki and Hassi (2011) conducted a study on consumers' 
current knowledge of sustainability in apparel production and utilization. Product's lifetime (76\%) and fiber cultivation (50\%) worried participants the most. Nearly half of the consumers worried about the manufacturing components such as product processing (47\%) and manufacturing location (46\%). However, consumers worried about the use phase the least (Table 2.2).

Table 2.2 Phases of the product life cycle that worry consumers (Niinimäki \& Hassi, 2011)

\begin{tabular}{cc}
\hline Phase & \% \\
\hline Lifetime of the product & 76 \\
Cultivation of fiber & 50 \\
Product processing & 47 \\
Location of manufacturing & 46 \\
Fiber processing & 35 \\
Transportation & 34 \\
Disposal of the product & 32 \\
Use phase (the use of water and energy) & 11 \\
\hline
\end{tabular}

From the industry's perspective, the Higg Index gives materials section (25\%) the most weight, followed by manufacturing (20\%) and product care and repair service (15\%). The Higg Index gives packaging (7.5\%) and transportation (7.5\%) the least weight, as reflected in Table 2.1. Based on the previous literature on consumer studies and Higg Index's weight distribution across different sections, the researcher hypothesizes that:

H1a: There exists a significant difference between the perspectives of the apparel industry and consumers on the importance of sustainable practices in different stages of the product life cycle. 
Existing research on consumers' willingness to pay for sustainable apparel products are mainly focused on sustainable materials and sustainable packaging. There are some contradictions on whether consumers are willing to pay a price premium on sustainable materials. Gam, Cao, Farr and Kang (2010) found that mothers were willing to purchase organic clothing for their children, but they were not willing to pay a premium. However, Ellis, McCracken and Skuza (2012) revealed that participants were willing to pay an average of $25 \%$ more for an organic cotton t-shirt. Similarly, Ha-Brookshire and Norum (2011) found that more than half of the consumers were willing to pay $\$ 5$ or more on a $\$ 30$ organic, sustainable and U.S. grown cotton t-shirt. Cao et al. (2014) used new materials such as eco-leather, bio-based materials and renewable materials to develop a pair of shoes and a coat. It was found that participants were willing to purchase apparel and footwear products from these materials if the products have adorable design and style. However, they were not willing to pay more for sustainable apparel materials.

Regarding sustainable packaging, Young (2008) did a cross-cultural consumer study and found that $67 \%$ of the consumers in the U.S. and $48 \%$ of the consumers in the UK were willing to pay a small amount more for environmentally friendly packaging, equivalent to 5-10 cents more. Only $23 \%$ of the consumers in China were willing to pay a price premium for sustainable packaging. Although consumers want to become more environmentally friendly, they do not want to spend additional money nor put a lot of effort on it (Laitala, Boks \& Klepp 2011).

Since limited research has been conducted in regards to consumers' willingness to pay on other sustainable practices, e.g., manufacturing, transportation, product care and repair, and end of use, this research intends to investigate consumers' 
willingness to pay a premium on different sustainable practices throughout the product life cycle. The researcher hypothesizes that:

H1b: Consumers' willingness to pay a premium on apparel industry's sustainable practices in different stages of the product life cycle does not match with the industry's perspective, as reflected by the Higg Index.

\subsection{Material}

\subsubsection{Industry Perspective}

Among the entire product life cycle, materials selection is of vital importance since it is the first step of being environmentally sustainable (University of Delaware Sustainable Apparel Initiative, 2009). The choices of materials would affect how the garments can be processed, cared for, and disposed (Chen \& Lewis, 2005). According to Muthu, Li, Hu and Mok (2009), the environmental concerns for materials include chemical management, energy consumption, ethical production and resource consumption. Particularly, associated issues include the quantity of water used in the agricultural production, dyeing, finishing and laundering garments, the use of hazardous chemical and its exposure to humans and environment, energy consumption and greenhouse gas emission, and the disposal of solid waste generated during manufacture of yarns, fabrics, and garments (Kirchain, Olivetti, Miller \& Greene, 2015).

In the apparel and textile industry, a large amount of hazardous chemicals are used during production (Fransson \& Molander, 2013). According to a study on 20 leading multinational companies in chemical management in the EU and the U.S., apparel companies' chemical management practices were especially focused on 
tracking and verifying suppliers' chemical performance, requiring full materials disclosure from suppliers, and minimizing the use of hazardous substances (Scruggs, 2013). Some companies accept third party certification systems in order to inform consumers that their products do not contain restricted substances (Scruggs, 2013). For example, Patagonia has partnered with Bluesign ${ }^{\circledR}$ systems to ensure that the materials they use meet the highest environmental and human safety standards (Romano, 2012). Furthermore, the big challenge for apparel companies' chemical management was to educate suppliers about companies' chemical-related demands and communication across the supply chain (Scruggs, 2013).

The Higg Index includes five parts in the Materials section: Materials Program, Restricted Substance List (RSL) Content and Transparency, Restricted Substance List (RSL) Verification, Chemical Impact Reduction Management, and Materials Selection and Approval Procedure. The Higg Index gives 10.5 points for the brands that have tracked and measured the environmental impacts from materials production and finishing. RSL provides the information related to regulations and laws that restrict certain chemicals and substances in the finished home textile, apparel, and footwear products (American Apparel and Footwear Association, 2013). The Higg Index gives 15 points to the brands that have adopted an industry-accepted standard RSL and have made RSL meet verification and certification requirements. Furthermore, the Higg Index gives 7.5 points to the brands who have worked with suppliers to reduce chemical impacts and who have verified materials durability as part of the material selection process, respectively. 


\subsubsection{Consumer Perspective}

Selecting sustainable materials is important for minimizing the overall environmental impacts throughout the product life cycle. Sustainability-oriented materials include organic fibers, naturally colored fibers, and recyclable fibers (Caniato, Caridi, Crippa \& Moretto, 2012). According to a survey conducted by Fulton and Lee (2013), organic materials (92\%) and pesticide free materials (66\%) were mostly used by online sustainable apparel brands. Specifically, organic cotton was used to produce garment by the most of online apparel brands including wellknown brands such as Patagonia, American Apparel and TS Designs (Fulton \& Lee, 2013). Accordingly, consumer perception toward purchasing organic cotton garments has always been at the center of previous literature. However, there are some contradictions on this topic. Hartman Group (2007) revealed that women were more likely to purchase organic cotton clothing than men, especially purchasing for their children. Gam et al. (2010) concluded that mothers' environmental concern, environmental purchase behavior and recycling behavior were found to be the significant factors for their involvement in organic cotton clothing. Ha-Brookshire and Norum (2011) found consumer attitude toward environment, age and gender significantly influenced their purchase behavior. However, Lin (2010) reported that there was no significant relationship between gender, age, education level, income, or ethnicity and consumers' willingness to purchase organic cotton clothing.

Furthermore, there is a growing market for post-consumer recycled garments due to the advanced technology and the increased environmental concerns (Chang, Chen, \& Francis, 1999). Previous studies have investigated consumer preference toward purchasing garments made from recycled materials. Hines and Swinker (1996) suggested that the majority of the participants would choose recycled apparel products 
if they have similar price compared with the traditional apparel products. In addition, environmentally conscious consumers with more knowledge related to recycling were more likely to purchase apparel products made from recycled materials. (Hines \& Swinker, 1996).

Previous research found that consumers have low interest and demand on chemical risks in apparel products (Boström, Börjeson, Gilek, Jönsson \& Karlsson, 2011; Fransson \& Molander, 2013). Parents of small children were more likely to know the chemical used in the apparel products than other types of consumers (Boström et al., 2011). Very limited study has been conducted on consumer perception regarding chemical management in the apparel products. This research intends to investigate consumer purchase preferences regarding different sustainable practices in apparel material selection process. Therefore, the researcher hypothesizes that:

H2: There exists a significant difference between the perspectives of the apparel industry and consumers on the importance of sustainable practices in materials.

\subsection{Packaging}

\subsubsection{Industry Perspective}

The essential function of packaging is to protect and deliver products to consumers in an optimal condition. At the same time, it has to satisfy consumer expectations on reducing environmental impacts (Nordin \& Selke, 2010). Several organizations have defined a common understanding on sustainable packaging within the industry. According to the Sustainable Packaging Alliance (SPA, www.sustainablepack.org), sustainable packaging should meet effective, efficient, 
cyclic and safety goals. Concretely, an effective goal means optimizing functionality and protecting products with minimal packaging. To be efficient, resource consumptions, solid waste and green house gas emission should be minimized throughout the product life cycle. A cyclic goal basically refers to recovering materials through the ways such as reuse or recycle. A safety goal means that package should be designed to minimize safety and health risks to humans and environment.

In the packaging section, the Higg Brand Module includes two parts: Packaging Program and Packaging Restricted Substance List (PRSL). Similar to the definition of sustainable packaging from SPA, packaging program part describes several ways for reducing environmental impacts such as reducing packaging design in weight, size or volume, tracking packaging materials, using less adhesives, labels or colorants, and increasing the use of recycled content. The Higg Index gives 4 points for each way above. PRSL part focuses on monitoring and verifying packaging materials to comply with brand PRSL regulations.

Apparel companies and organizations have been making effort to produce environmentally friendly packaging. For example, Levi's sold their products in recycled paper packaging and printed with soy-based ink (Kim, 2008). Wal-Mart Stores, Inc. released a packaging scorecard to its suppliers, aiming at reducing waste across its global supply chain and improving sustainable packaging. The Sustainable Packaging Coalition (SPC, www.sustainablepackaging.org), a U.S. nonprofit organization, published the guidelines for sustainable packaging. In Australia, the Sustainable Packaging Alliance (SPA) is an initiative, dedicated to establishing networks and events for packaging business stakeholders. Furthermore, various ecodesigned tools have been developed in order to evaluate and improve sustainable 
packaging including Packaging Impact Quick Evaluation Tool, Comparative Packaging Assessment and Package SMART (Martinho, Pires, Portela \& Fonseca, 2015).

\subsubsection{Consumer Perspective}

Packaging is one of the important attributes that would differentiate the products and thereby drive consumer purchase decisions (Michon, Yu, Smith \& Chebat, 2008). The existing research has investigated consumers' knowledge, attitude and behavior on sustainable packaging (Scott \& Vigar-Ellis, 2014; Young, 2008). According to Young (2007), only $11 \%$ of the consumers have heard the term "sustainable packaging" and known what it means. Furthermore, in the contrast with the industry's understanding of sustainable packaging, $49.2 \%$ of the participants cited sustainable package as not harmful to humans and environment, while $41.2 \%$ considered as degradable and $36.5 \%$ considered as recyclable (Scott \& Vigar-Ellis, 2014). Young (2008) revealed that most global consumers understood sustainable package as "made from recyclable materials" and half of the U.S. consumers perceived sustainable package as "durable packaging". Although the majority of consumers around the world associated sustainable packaging with recycling, they had limited knowledge about what types of package material can be recycled (Nordin \& Selke, 2010).

While most of consumers are increasingly aware of the environmental issues, there exists a gap between consumer attitude and behavior (Nordin \& Selke, 2010). Previous research indicated that consumer purchase behavior toward packaging was first driven by package quality and functionality, and then followed by environmental considerations (Young, 2008). In addition, 30\% of the 22000 U.S. consumers ranked 
packaging as the second important sustainability consideration that influenced their selection of brands and products (Information Research Institute, 2007). Consumers also believed that manufacturers should take more responsibility than themselves on sustainable packaging (Nordin \& Selke, 2010). Regarding sustainable apparel packaging, according to a survey conducted by Connell and Kozar (2012), 32.3\% of the 200 consumers preferred purchasing clothing with environmental conscious labeling or packaging. Existing literature has been focused on general consumer attitude and behavior on sustainable packaging or consumer perception on other types of packaging such as food. Little is known about consumer insight on sustainable apparel packaging. Therefore, the researcher hypothesizes that:

H3: There exists a significant difference between the perspectives of the apparel industry and consumers on the importance of sustainable practices in packaging.

\subsection{Manufacturing}

\subsubsection{Industry Perspective}

Apparel and textile manufacturing involves cutting, sewing, dyeing, printing and finishing process. Each production stage incurs many kinds of negative impacts on environment such as energy use, chemical use and water consumption (Khan \& Islam, 2015). For example, dyeing and printing process makes intensive use of toxic chemical and heavy metals in the forms of inks and colorants. Garment finishing process requires a significant amount of water and energy, and applies chemicals to enhance fabric properties. Chemicals, dyes and detergents are discharged in the wastewater since they are difficult to remove from water (Khan \& Islam, 2015). Due 
to the low efficiency and the complexity of pattern, $6 \%-25 \%$ of the solid waste will be created during cutting, sewing and trimming process (Ljungberg, 2007). In the Higg Brand Module, the manufacturing section also includes water use and manufacturing efficiency. The Higg Index gives 20 points for the brands that have saved and documented water usage, and gives 5 points for the brands that have monitored manufacturing efficiency in the supply chain. Additionally, the Higg Index gives 5 points for the brands that have reduced the environmental impacts associated with sampling. However, the Higg Index does not mention sustainable practices regarding energy use and chemical use.

With an increasing emphasis on sustainability, it is important to consider environmental factors when making supplier selection decisions (Bai \& Sarkis, 2010). The Higg Index gives 20 points for the brands that have developed and issued environmental guidelines to its manufacturing suppliers in order to improve environmental performance. Furthermore, many apparel companies differentiate their products and show the evidence of their environmental-related practices by adopting the verified certification via third parties such as ISO 14000 (Subic, et al., 2012). The Higg Index also emphasizes on suppliers continuous improvement program and gives 15 points to the brands that have encouraged their suppliers to drive environmental performance improvement.

\subsubsection{Consumer Perspective}

According to a consumer study conducted by Fredriksson and Ytterfors (2015), all of the participants mentioned that the apparel manufacturing process affects environment a lot. However, no one could exactly tell what the manufacturing process included. When defining sustainable apparel production, some participants mentioned 
the types of materials used and their origins. Others mentioned the amount of water consumed in the production process and the working conditions in the factories. Hill and Lee (2012) found that $51.3 \%$ of the participants and $50.1 \%$ of the participants chose water consumption and solid waste as the most important sustainability issues during apparel production and consumption, respectively. Lack of research has investigated consumer perception toward environmentally friendly manufacturing. This research aims to discover consumer purchase preferences regarding different sustainable practices in the apparel manufacturing process. Therefore, the researcher hypothesizes that:

H4: There exists a significant difference between the perspectives of the apparel industry and consumers on the importance of sustainable practices in manufacturing.

\subsection{Transportation}

\subsubsection{Industry Perspective}

The apparel industry is a global industry, where most products are produced outside the country. It is common to transport products from factories in the East to stores in the West (Burns \& Bryant 2002). According to the American Apparel \& Footwear Association (2015), nearly $97 \%$ of the apparel products sold in the United States are imported from abroad. Transportation stage was often overlooked due to the minor contribution to the overall environment compared with other stages (Chapman, 2010). However, transportation is a significant contributor of green house gas emission. Especially for fast fashion brands, which requires quick response, companies usually chose the most efficient transportation method (Fredriksson \& 
Ytterfors, 2015). Although every transportation option will affect the environment in some forms, apparel companies could change their shipping practices to significantly reduce the pollution footprint.

In the Higg Brand Module, the transportation section includes optimizing model type, distance, and weight/volume, maximizing the utilization of transportation assets, and selecting environmentally friendly carriers. Many companies have been improving the transportation practices and reducing the amount of carbon emission. For example, according to the H\&M sustainability report, they avoided air and road transports, and $90 \%$ of their products were transported via sea or rail. Furthermore, H\&M provided training to their carriers and collaborated with transport providers in order to have the least possible impacts on the environment (Walker, 2012).

\subsubsection{Consumer Perspective}

According to Hanss and Böhm (2012), consumers highlighted carbon dioxide emission during shipping as an important attribute for sustainable products. Similarly, when evaluating consumer perception of sustainable practices in the apparel industry, $18.9 \%$ of the consumers ranked environmentally friendly shipping containers as the most important factor, while $26.4 \%$ of the consumers ranked it as the least important (Hill \& Lee, 2012). In addition, $22.45 \%$ of the consumers thought they have no knowledge about sustainable shipping containers (Hill \& Lee, 2012). According to a study conducted by Fredriksson and Ytterfors (2015), 30\% of the consumers stated that transportation is a key component that apparel companies should consider in addressing environmental problems. Consumers mentioned several sustainable ways of transportation, e.g., loading the cargos efficiently, avoiding transport by air, and optimizing the transport routes. A few participants would like to be informed more 
about companies' sustainable transportation choices. In light of limited existing research, the researcher hypothesizes that:

H5: There is no significant difference between the perspectives of the apparel industry and consumers on the importance of sustainable practices in transportation.

\subsection{Product Care \& Repair Service}

\subsubsection{Industry Perspective}

The sustainability in the clothing utilization stage refers to the resources used to take care of an apparel product during its useful life, such as laundering, bleaching, drying and ironing (Moon et al., 2013). Previous literature has found that the most significant environmental impacts occurred during the consumer use phase (Allwood et al., 2006; Chen \& Burns, 2006). For example, according to a blouse life cycle study, a large amount of the environmental effects such as energy consumption, solid waste, carbon dioxide, and biological oxygen demand were aroused from the clothing use stage (Fletcher, 2008). Furthermore, when evaluated from the perspective of clothing life cycle assessment, the consumer use period is the most energy demanding (Laitala \& Boks, 2012). According to Fletcher (2008), laundering alone accounted for $82 \%$ of the energy use during the clothing life cycle. Similarly, Allwood et al. (2006) indicated that $60 \%$ of the energy consumption in a cotton T-shirt was associated with washing and drying. A study on the life cycle of a pair of Levi's jeans showed that $23 \%$ of the water was used and $37 \%$ of the carbon dioxide was emitted during the consumer use phase (Badore, 2015). Accordingly, eco-labels and low impact instructions are provided by many apparel companies. For example, Levi Strauss \& Co. passed the message of "Wash less, wash in cold, line dry, and donate when no 
longer needed" to consumers on all global products' care tags (Vestel, 2009). In the Higg Brand Module, criteria related to the product care include design for durability and longevity and product care communication. The Higg Index gives 14 points for the brands that have enhanced product durability and maximized product useful life, and gives 12 points for those who have made low impact care instructions publicly available and easily accessible for consumers.

Another aspect in the consumer use phase is clothing repair. According to Fletcher (2010), many fast fashion products on today's market cannot last long due to the poor quality. At the same time, the cheap price encourages consumer to replace products quickly, causing additional environmental effects from production and disposal stages. However, some apparel companies such as Patagonia, Flint and Tinder, and Tom Cridland are making effort on keeping and repairing their old products. For example, Patagonia provides step-by-step repair guides on their websites and offers repair service for the products consumers sent back to them (Becker, 2016). Tom Cridland offers 30 years guarantee sweatshirt and T-shirt to its consumers (Luecke, 2015). If consumers' sweatshirt or T-shirt is damaged within the 30-year warranty, Tom Cridland will repair it for free. In the Higg Brand Module, criteria related to product repair include reparability design standards and repair service communication. The Higg Index gives 18 points for the brands that have maximized product repairable and upgradable features when designing products, and gives 12 points to those who have communicated their repair program with consumers.

\subsubsection{Consumer Perspective}

The way consumers take care of clothing has a huge negative impact on the environment. Unnecessarily frequent washing, high washing temperature, excessive 
use of detergents and tumble drying would shorten clothing longevity (Allwood et al., 2006). Taking laundering as an example, technological improvements in washing machines and the appearance of environmentally friendly detergents have reduced the total environmental impacts per wash. However, the increasing washing frequencies and the amount of clothing consumers own have impeded these improved technologies (Fisher, Cooper, Woodward, Hiller \& Goworek, 2008). According to a study on consumers laundry habits conducted in Norway, the majority of the participants measured dosage based on eyes. Only $12 \%$ of the participants followed detergent usage instructions and used the measuring cup (Laitala, Klepp \& Boks, 2012). A study on laundry practices in Germany indicated that consumers did not vary detergent dosage based on the type of garments, soiling level and the amount of laundering (Kruschwitz et al., 2014). Moreover, washing machines tend to be under loaded if consumers were washing with different sorting categories (Laitala, Klepp \& Boks, 2012). Consumers were unwilling to fill the machine since they were worried about the cleanness (Laitala, Klepp \& Boks, 2012; Kruschwitz et al., 2014).

Consumers care behavior not only relates to the development of technology but also relates to the accessibility of information and willingness to change (Laitala, Boks \& Klepp, 2011). Almost all clothing are attached with the information such as size, country of origin, fiber content and care instructions, presented in the forms of labels or hang tags (Laitala \& Klepp, 2013). Although brands intend to make care information publicly available and easily accessible for consumers, the level of understanding and following of these instructions by consumers were relatively low (Thøgersen, 2000). It was also found that consumers were confused with the various labels, which inhibited them to use it correctly (Hanss \& Böhm, 2012). Furthermore, 
previous literature revealed that consumers were reluctant to follow the information on care labels but relied on their experience and knowledge instead (Laitala \& Klepp, 2013; El-Dessouki, 2015).

Regarding clothing repair service, according to Ryttinger and Holtmaat (2014), consumers repair behavior associated with various factors including the value of garments, the available of materials and repair skills. Previous research has shown that consumers had limited skills on clothing repair, which inhibited the acceptance of sustainable practices through the utilization stage (Fisher et al., 2008; Laitala \& Boks, 2012; Norum, 2013). Consumers preferred to fix some simple repairs such as attaching a button or sewing an unraveled seam (Ryttinger \& Holtmaat, 2014). Similarly, Laitala and Boks (2012) revealed that consumers were more likely to repair simple tasks: sewing on a button (73\%), fixing an unraveled seam (55\%), patching clothes $(31 \%)$, darning clothes $(27 \%)$, and fixing trouser length $(26 \%)$. However, most consumers were unable to solve advanced repairs such as replacing a zipper. In addition, consumers preferred to dispose or replace with a new garment than to repair the old one since most of the clothing today is affordable (Ryttinger \& Holtmaat, 2014). In light of consumer attitude and behavior toward product care and repair services, the researcher hypothesizes that:

H6: There is no significant difference between the perspectives of the apparel industry and consumers on the importance of sustainable practices in product care and repair service. 


\subsection{End of Use}

\subsubsection{Industry Perspective}

Due to the low price and new styles, fast fashion not only stimulates consumers to purchase new products more frequently, but also accelerates the dispose rate. The desire of catching up with the latest fashion trends and impulse purchasing lead that many garments were thrown away only after worn a few times or even had never worn at all (Birtwistle \& Moore, 2007). As a result, textile waste has increased from $7 \%$ to $30 \%$ by weight in the past five years, indicating that consumers are disposing more clothing than before (Morgan \& Birtwistle, 2009). Furthermore, clothing disposal problem becomes increasing serious in the world. For example, $30 \%$ of the clothing waste was sent to charities, $10 \%$ was incinerated and the remaining $60 \%$ was sent to the landfills (Allwood et al., 2006). More specifically, nearly one million tons of waste end up in landfills every year in UK (Defra, 2009). Approximately 4.5\% of U.S. landfills were composed of post-consumer textile waste (Hammer, 1993). However, according to the U.S. Environmental Protection Agency (2013), only 14.8\% of the 12.4 million tons of the textile solid waste were recovered.

According to the Higg Brand Module, the ultimate goal of End of Use (EOU) is to divert post-consumer waste from the landfills as much as possible. End of Use consists of three streams: reuse, repurpose and recycling. Reuse refers to donating products to charities, friends and families, selling used products in second-hand stores, and giving products to recycling enterprise for resale in the same form. Repurpose relates to giving or selling products to a private enterprise in new forms such as wipers or rags. Currently, a growing number of companies are working with charities to address clothing disposal problems. For example, British apparel company $M \& S$ 
worked with Oxfam by offering $£ 5$ off when donating $M \& S$ labeled clothing to an Oxfam shop (Oxfam, 2012). Levi Strauss \& Co. partnered with Goodwill by giving $\$ 5$ on every box of donated clothing (Koenig, 2015). The Higg Index gives 20 points to the brands that have developed partnerships with organizations or provided product take-back service.

Recycling can be classified as upcycling and downcycling. The former type is a recycle where the original value of the material is maintained or enhanced, while the latter one happens when the property of the material is degraded. The main difficulty for clothing recycling is that the combination of materials such as natural and synthetic fibers, dyes and trimmings is hard to separate (Chen \& Burns 2006). The Higg Index gives 30 points for the brands that have designed products with the material types which can be separated for recycling. Furthermore, the Higg Brand Module also mentions that brands should publicly communicate one or more streams with consumers through a variety of channels and gives 12 points for the brands that have performed well on this criterion.

\subsubsection{Consumer Perspective}

Sustainable consumer behavior involves pre-purchase, purchase and postpurchase (Jacoby, Berning \& Dietvorst, 1977). Post-consumer waste is defined as any type of clothing that the owner no longer needs and decides to discard (Hawley, 2006). Previous literature has investigated the reasons for clothing disposal (Table 2.3). Klepp (2001) found that the participants disposed used clothing primarily due to quality problem, psychological reason (e.g. tired of the product) and situational reason (e.g. changed body size). $13 \%$ of the participants disposed clothing because of impulse purchasing and had never worn at all. Similarly, Cooper, Fisher, Hiller, Goworek and 
Woodward (2010) revealed that the reasons for clothing disposal include clothing condition, new fashion trend, lack of space, loss emotional attachment and fit problem. As a result, many garments are thrown away before their potential lifetime.

Table 2.3 Reasons for disposal of clothes in study of 24 Norwegian women (Klepp, 2001)

\begin{tabular}{lc}
\hline \multicolumn{1}{c}{ Type of obsolescence } & $\begin{array}{c}\text { Percentage of } \\
\text { total number of } \\
\text { registered } \\
\text { reasons }\end{array}$ \\
\hline $\begin{array}{l}\text { Technical or quality related (The product is worn out, ruined or is } \\
\text { uncomfortable in use.) }\end{array}$ & $35 \%$ \\
$\begin{array}{l}\text { Psychological (The owner is tired of the product, does not use that } \\
\text { style anymore, or clothes seem outdated) }\end{array}$ & $31 \%$ \\
$\begin{array}{l}\text { Situational (The owner has developed new needs, such as changed } \\
\text { body size, has other similar clothes and lacks closet space, or that } \\
\text { the clothes have too narrow use area) }\end{array}$ & $19 \%$ \\
$\begin{array}{l}\text { Never worn (Product not suitable for purpose. Often bought on } \\
\text { impulse or received as present) }\end{array}$ & $13 \%$ \\
$\begin{array}{l}\text { Functional (New and better products have come to the market) } \\
\text { Sentimental (The owner takes the product out of use and keeps it } \\
\text { for other purpose, does not want to use it in order to not to ruin it) }\end{array}$ & $1 \%$ \\
\hline
\end{tabular}

Furthermore, consumers did not have a specific idea on how long they should keep the clothing since no garment includes the information about expected lifespan (Birtwistle \& Moore, 2007). Laitala and Klepp (2011) indicated that the most common disposal frequency was once or twice a year (48\%). Women were believed to dispose clothing more frequently than men. For those clothing that is no longer used but not 
worn out, most consumers donated them to charities or gave them to friend or families (Laitala \& Klepp, 2011). Similar result was found in a survey conducted by Morgan and Birtwistle (2009). The majority of the usable clothing (36\%) was given to charity, nearly $25 \%$ of the apparel items were given to family members or friends, and $20 \%$ of the clothing was reused at home. For those clothing that is no longer wearable, a large portion was thrown to the garbage. Only a few were repaired or reused in other forms. Moreover, previous research found that the convenience of recycling plays a central role in consumer disposal behavior (Birtwistle \& Moore, 2007). In general, consumers were still lacking of knowledge in regards to how and where clothing should be disposed in an environmentally friendly way (Birtwistle \& Moore, 2007). Based on the information above, the researcher hypothesizes that:

H7: There exists a significant difference between the perspectives of the apparel industry and consumers on the importance of sustainable practices in end of use. 


\section{Chapter 3}

\section{METHODOLOGY}

The purpose of this study is to investigate consumer preference on the apparel industry's sustainable practices throughout the product life cycle, and further to find out whether consumers are willing to pay a premium for these practices. The researcher proposes seven hypotheses, corresponding to the three research objectives, as shown in Table 3.1. This chapter gives a detailed description of the processes of data collection and methods of data analysis.

Table 3.1 Objectives and of hypotheses in this research

\section{Objective \\ Hypothesis}

1. Identify consumer acceptance of industry's sustainable practices across the product life cycle, including material, manufacturing, packaging, transportation, product care and end of use.

2. Identify consumers' willingness to pay a premium on industry's sustainable practices across the product life cycle, including material, manufacturing, packaging, transportation, product care and end of use.
H1a: There exists a significant difference between the perspectives of the apparel industry and consumers on the importance of sustainable practices in different stages of the product life cycle.

H1b: Consumers' willingness to pay a premium on apparel industry's sustainable practices in different stages of the product life cycle does not match with the industry's perspective as reflected by the Higg Index 
3. In each stage of the product life cycle, i.e., material, manufacturing, packaging, transportation, product care and end of use, identify consumer acceptance of industry's sustainable practices.
H2: There exists a significant difference between the perspectives of the apparel industry and consumers on the importance of sustainable practices in materials.

H3: There exists a significant difference between the perspectives of the apparel industry and consumers on the importance of sustainable practices in packaging.

H4: There exists a significant difference between the perspectives of the apparel industry and consumers on the importance of sustainable practices in manufacturing.

H5: There is no significant difference between the perspectives of the apparel industry and consumers on the importance of sustainable practices in transportation.

H6: There is no significant difference between the perspectives of the apparel industry and consumers on the importance of sustainable practices in product care and repair service.

H7: There exists a significant difference between the perspectives of the apparel industry and consumers on the importance of sustainable practices in end of use. 


\subsection{Sample}

An online survey was used to collect consumers' perspectives regarding the apparel industry's different sustainable practices. The participants for this study were recruited using “Amazon Mechanical Turk", which serves as a convenient platform for constructing surveys and collecting responses (Mason \& Suri, 2012). Participants at Mechanical Turk are coming from a diverse background with a wide range of age, ethnicity, education background, etc. Researchers could filter bad responses by identifying the time spent on completing the tasks or low effort responses such as always choosing one option (Mason \& Suri, 2012). Moreover, since participants on Mechanical Turk are paid after completing the survey, they are more likely to finish it once they start (Göritz, 2006). In order to improve the quality of the data, the researcher required all participants to be Masters in Mechanical Turk who have completed a wide range of tasks and maintained the Mechanical Turk Masters Qualification. All participants were based in the United States and have to be 18 years or older. The participants were given consent form that introduced the type of activity they would be engaging in and that guaranteed their anonymity. All participants need to agree the consent form before answering the questions. There are some compensation for participating in this study. Participants would be paid $\$ 1.00$ for carefully and completely responding to the questionnaire in this research project.

\subsection{Procedure}

Prior to collecting data, the Institutional Review Board (IRB) reviewed the proposed study and survey, and approved the use of human subjects. The online survey was conducted using Qualtrics, an online survey software to collect data. Selfadministered questionnaire that contained 38 questions and an open-ended question 
were distributed to each participant. Questions asking consumer acceptance of the apparel industry's sustainable performance were obtained from the Higg Brand Environmental Module. The Higg Brand Environmental Model includes seven sections, i.e., the general section, materials, packaging, manufacturing, transportation, product care and repair service, and end of use. Each section has 100 points with different weight distribution, as reflected in Table 2.1. Therefore, the total maximum points for a company is 100 points. The general section was not included in the questionnaire since the questions are related to companies' overall internal management, which is too technical for consumers to understand and less relevant to consumers. The rest six sections cover the different stages throughout the product life cycle. The researcher selected questions from these six sections, including four questions related to materials, packaging, product use and end of use, five questions related to manufacturing and three questions related to transportation. Since the Higg Index is used by apparel professionals, the original Higg Index questions were rephrased by using non-technical language in order to make them understandable to general consumers.

The questionnaire began with two questions asking if participants have sufficient knowledge about the apparel products as well as the environmental impacts related to apparel production and utilization. Then the participants were required to indicate their preference on environmentally friendly apparel products throughout the product life cycle, including materials, packaging, manufacturing, transportation, product care and repair service, and end of use. These questions were scored on a 5point Likert item scale, ranging from 1 indicating strongly disagree through 5 indicating strongly agree. The researcher further asked how much more the consumers 
are willing to pay for apparel companies' sustainable practices from these six sections. The last part contained questions asking demographic information such as gender, age, race, education status and household income. A script used for administering the questionnaire can be found in Appendix B.

\subsection{Data Analysis}

JMP software (SAS Institute; Cary, North Carolina) was used to conduct data analysis. First, descriptive statistics were used to describe the demographic information of the participants and identify their knowledge on apparel products as well as the environmental issues related to the apparel industry. Second, Cronbach's alpha reliability coefficient was used to test whether the groups of items in each section of the Higg Index were highly internally consistent. Cronbach's alpha is the most common reliability assessment, ranging from 0 to 1 . The higher the score, the more reliable the construct is (Nunnaly, 1978). Third, the researcher used chi-square goodness of fit test to investigate whether there exists a significant difference on the weight distribution of sustainable practices between the perspectives of the industry and consumers. Chi-square goodness of fit test is used to determine whether the distribution of the sample data is consistent with a hypothesized distribution. As higher weight indicates higher importance, this test could discover the importance of sustainable practices in different perspectives throughout the product life cycle. Since the Higg Index has different weight distribution across different sections and different point distribution on questions within each section, the researcher first compared the overall weight distribution and further compared point distribution within each section between the Higg Index and the sample data in order to test the hypotheses. 


\section{Chapter 4}

\section{RESULTS AND DISCUSSION}

\subsection{Descriptive Statistics}

The survey was carried out as an online survey in spring 2016 in the United States. A total of 250 respondents participated in the survey. Table 4.1 provides the description of the sample. Of the participants, $57 \%$ were female and $43 \%$ were male. Most of the participants were between the ages of 25 to $34(41 \%)$. The majority of the participants were white $(77 \%)$. In terms of education status, half of the participants had a bachelor degree (50\%) and $42 \%$ completed only high school degree. When describing their household income, most of the participants (26\%) reported their household income before tax to be in the range of $\$ 50,000$ to $\$ 74,999$. According to the data from United States Census Bureau in 2014 (United States Census Bureau, 2014), the majority of Americans were white (77.4\%) and most of them achieved a high school degree or higher $(86.3 \%)$. The largest proportion of US household income was in the range of $\$ 50,000$ to $\$ 74,999(17 \%)$. The distribution of the participants in this research is consistent with the data from USCB and could represent general consumers in the U.S. 
Table 4.1 Demographic profile of participants $(\mathrm{N}=250)$

\begin{tabular}{|c|c|c|c|}
\hline Variable & Description & Frequency & $\%$ \\
\hline \multirow[t]{2}{*}{ Gender } & Women & 142 & 57 \\
\hline & Men & 108 & 43 \\
\hline \multirow[t]{6}{*}{ Age } & 18-24 years & 13 & 5 \\
\hline & 25-34 years & 103 & 41 \\
\hline & $35-44$ years & 66 & 26 \\
\hline & $45-54$ years & 41 & 16 \\
\hline & $55-64$ years & 22 & 9 \\
\hline & 65 years or older & 5 & 2 \\
\hline \multirow[t]{7}{*}{ Race/Ethnicity } & African American/Black & 20 & 8 \\
\hline & Asian/Pacific Islander & 18 & 7 \\
\hline & Hispanic/Latino & 12 & 5 \\
\hline & Multiracial & 2 & 1 \\
\hline & Native American/American Indian & 3 & 1 \\
\hline & White & 193 & 77 \\
\hline & Not Listed & 2 & 1 \\
\hline \multirow[t]{5}{*}{ Education Status } & Less than high school & 2 & 1 \\
\hline & High school or equivalency & 105 & 42 \\
\hline & Bachelor's degree & 124 & 50 \\
\hline & Master's degree & 15 & 6 \\
\hline & Beyond Master's degree & 4 & 2 \\
\hline \multirow{7}{*}{$\begin{array}{l}\text { Household Income } \\
\text { before tax }\end{array}$} & Less than $\$ 25,000$ & 49 & 20 \\
\hline & $\$ 25,000$ to $\$ 34,999$ & 50 & 20 \\
\hline & $\$ 35,000$ to $\$ 49,999$ & 46 & 18 \\
\hline & $\$ 50,000$ to $\$ 74,999$ & 66 & 26 \\
\hline & $\$ 75,000$ to $\$ 99,999$ & 20 & 8 \\
\hline & $\$ 100,000$ to $\$ 149,999$ & 14 & 6 \\
\hline & $\$ 150,000$ or more & 5 & 2 \\
\hline
\end{tabular}

Table 4.2 provides a summary of consumers' knowledge about apparel products as well as the environmental impacts generated in apparel production and utilization process. Of the participants, $82.8 \%$ agreed or strongly agreed that they were familiar with apparel products and 51.2\% agreed or strongly agreed that they knew the environmental impacts associated with the apparel industry well. 
Table 4.2 Descriptive statistics on participants' knowledge

\begin{tabular}{llllll}
\hline Questions & $\begin{array}{l}\text { Strongly } \\
\text { disagree }\end{array}$ & Disagree & Neutral & Agree & $\begin{array}{l}\text { Strongly } \\
\text { agree }\end{array}$ \\
\hline $\begin{array}{l}\text { I have sufficient knowledge } \\
\text { about apparel products }\end{array}$ & $1.60 \%$ & $4.40 \%$ & $11.20 \%$ & $66.40 \%$ & $16.40 \%$ \\
$\begin{array}{l}\text { I have sufficient knowledge } \\
\text { about environmental impacts } \\
\text { related to apparel production } \\
\text { and utilization process }\end{array}$ & $4.00 \%$ & $16.00 \%$ & $28.80 \%$ & $42.40 \%$ & $8.80 \%$ \\
\hline
\end{tabular}

\subsection{Reliability Analysis}

Cronbach's coefficient alpha was used to test the internal consistency of the six multi-item variables: materials, packaging, manufacturing, transportation, product care and repair service, and end of use. Each variable represents a different stage of the product life cycle, the same as each section in the Higg Brand Environmental Module. Cronbach's alpha is the most common reliability assessment, where a value of $>0.7$ is commonly considered to indicate a satisfactory level of the internal consistency of data (Nunnally, 1967). Table 4.3 provides a summary of reliability assessment for the measures. The Cronbach's alpha coefficients for each construct ranged from 0.74 to 0.91, indicating that all multi-item variables were internally consistent.

Table 4.3 Reliability test using Cronbach's alpha

\begin{tabular}{ccccc}
\hline Variables & Alpha & Mean & Variance & No. of items \\
\hline Materials & 0.793 & 3.971 & 0.907 & 4 \\
Packaging & 0.890 & 3.947 & 0.873 & 4 \\
Manufacturing & 0.904 & 3.837 & 0.856 & 5 \\
Transportation & 0.912 & 3.749 & 0.984 & 3 \\
Product Care and Repair Service & 0.736 & 4.266 & 0.644 & 4 \\
\hline
\end{tabular}




\subsection{Comparison between the Perspective of Industry and Consumers}

To test if consumers' perspective follows the industry's perspective on different stages of the product life cycle, the researcher conducted the chi-square goodness of fit tests. The results are presented in Table 4.4. Because of inherent consistency, the answers in each variable were combined together for analysis. There exists a significant difference between the industry and consumers on the overall weight distribution $(\mathrm{p}<.05)$. Therefore, hypothesis H1a was accepted: There exists a significant difference between the perspectives of the apparel industry and consumers on the importance of sustainable practices in the clothing life cycle.

Table 4.4 Comparing consumers' perspective and industries' perspective on different stages of the product life cycle

\begin{tabular}{cccccccc}
\hline Variables & $\begin{array}{c}\text { Higg } \\
\text { Weights }\end{array}$ & $\begin{array}{c}\text { Estim } \\
\text { Prob } \\
\text { (Based on } \\
\text { Higg } \\
\text { weights) }\end{array}$ & $\begin{array}{c}\text { Mean } \\
\text { of } \\
\text { consumers' } \\
\text { response }\end{array}$ & $\begin{array}{c}\text { Hypoth } \\
\text { Prob } \\
\text { (Based on } \\
\text { Mean) }\end{array}$ & $\chi^{2}$ & DF & p \\
\hline Materials & 25 & 0.294 & 3.971 & 0.170 & 34.41 & 5 & $<.01$ \\
Packaging & 7.5 & 0.088 & 3.947 & 0.169 & & & \\
Manufacturing & 20 & 0.235 & 3.837 & 0.164 & & & \\
Transportation & 7.5 & 0.088 & 3.750 & 0.160 & & & \\
Product Care & 15 & 0.176 & 4.266 & 0.182 & & & \\
and Repair & 10 & 0.118 & 3.638 & 0.156 & & & \\
End of Use & 10 & & & & &
\end{tabular}

The Higg Index gives the product care and repair service section 15\% weight distribution, ranking it as the third importance, while consumers have the highest 
preference (Mean=4.27) for the companies that have adopted sustainable performance in the product use phase. The findings support Niinimäki and Hassi's (2011) publication that consumers think highly of clothing care and repair. Niinimäki and Hassi (2011) conducted a study on exploring design and manufacturing strategies that could reduce the environmental impacts during apparel production and consumption. When asked about consumer interest toward these strategies, $86 \%$ of the participants were interested in repair and modification services. Furthermore, $60 \%$ stated that they preferred clothing with detachable parts so that they could make modifications. This finding suggests that the product use phase is closely related to consumers. Consumers are pleased to see that apparel companies are making efforts on those sustainable practices that directly benefit them. Considering that the consumer use phase contributes a large portion of the overall environmental impacts throughout the clothing life cycle (Allwood et al., 2006), the findings suggest that the Higg Index might consider increasing the weight accordingly to take consideration of consumers' opinions and raise the awareness on this section. At the same time, apparel companies are suggested to offer low impact instructions and repair guidance as well as to provide consumers substitute textile fabric and accessories such as zippers or buttons (Goworek, Fisher, Cooper, Woodward \& Hiller, 2012).

The Higg Index assigns the manufacturing section for a weight of $20 \%$, ranking it as the second important section. However, participants in this research did not give a high preference regarding the sustainable efforts in the apparel manufacturing process. There are some contradictions between the current finding and Hill and Lee's (2012) publication. Hill and Lee (2012) conducted a research towards consumer perception of sustainability in the apparel industry. When asked to choose 
five items from a list of sustainable practices that they considered the most and least important, at least half of the participants chose manufacturing components, i.e., “energy efficiency" (58.8\%), "fabric waste reduction" (51.3\%) and "water usage control" (50.1\%). The inconsistency between current study and Hill and Lee's (2012) publication might be due to the difference of participants. The participants in Hill and Lee's (2012) research were 80 female students, aged 18-25, majoring in textiles and apparel at a large university in the U.S. This sample only focused on the young generation with professional training, and thus could not represent general consumers in the U.S. Students concentrating in the textiles and apparel major may have more exposure to sustainability and know the large amount of environmental effects generated during apparel production. According to a study conducted by Fredriksson and Ytterfors (2015) on comparing consumers' and companies' views regarding sustainability, they found that general consumers have a poor knowledge of the environmental issues in apparel production process. Therefore, the findings suggest that apparel companies should communicate their sustainable related practices to consumers in order to educate them on environmental knowledge in the apparel manufacturing phase.

The Higg Index gives packaging section the least weight, indicating that little attention and efforts were given by the industry. However, the findings of this research support Hill and Lee's (2012) publication that consumer view product packaging as an important factor when addressing environmental impacts. Particularly, $43.9 \%$ of the participants in Hill and Lee's (2012) study listed recycle packaging materials as the most important environmental issues. Therefore, this research suggests that the Higg Index need to increase their awareness towards product packaging since it results in a 
large proportion of the resources consumed and waste generated by consumers (Ritch, Brennan \& MacLeod, 2009). At the same time, apparel companies should continue taking steps to design sustainable packaging in order to fill the needs of consumers as well as to reduce the environmental footprint.

\subsection{Willingness to Pay}

In the survey, participants were asked about how much more they are willing to pay for the industry's sustainable practices through the product life cycle. The results are summarized in Table 4.5. Among all sections but the end of use section, the majority of the participants is willing to pay $1-5 \%$ more for sustainable practices. Regarding sustainable performance related to the clothing end of use, $37 \%$ of the participants are willing to pay $1-5 \%$ more, and $37 \%$ of the participants are not willing to pay at all.

Table 4.5 Consumers' willingness to pay on different stages of the product life cycle

\begin{tabular}{|c|c|c|c|c|c|c|c|c|c|}
\hline & $\mathbf{0}$ & $\begin{array}{c}1- \\
5 \%\end{array}$ & $\begin{array}{c}6- \\
10 \%\end{array}$ & $\begin{array}{c}11- \\
15 \%\end{array}$ & $\begin{array}{c}16- \\
20 \%\end{array}$ & $\begin{array}{c}21- \\
25 \%\end{array}$ & $\begin{array}{c}26- \\
30 \%\end{array}$ & Other & $\begin{array}{c}\text { Mean* } \\
(\% \\
\text { more })\end{array}$ \\
\hline Material & $12 \%$ & $32 \%$ & $28 \%$ & $14 \%$ & $9 \%$ & $3 \%$ & $1 \%$ & $1 \%$ & 8.27 \\
\hline Packaging & $27 \%$ & $39 \%$ & $22 \%$ & $8 \%$ & $2 \%$ & $2 \%$ & $1 \%$ & $0 \%$ & 4.87 \\
\hline Manufacturing & $18 \%$ & $40 \%$ & $26 \%$ & $7 \%$ & $6 \%$ & $2 \%$ & $1 \%$ & $0 \%$ & 6.20 \\
\hline Transportation & $30 \%$ & $40 \%$ & $17 \%$ & $8 \%$ & $2 \%$ & $2 \%$ & $1 \%$ & $0 \%$ & 4.87 \\
\hline $\begin{array}{l}\text { Product Care } \\
\text { and Repair }\end{array}$ & $17 \%$ & $34 \%$ & $29 \%$ & $9 \%$ & $6 \%$ & $3 \%$ & $2 \%$ & $1 \%$ & 7.20 \\
\hline End of use & $37 \%$ & $37 \%$ & $16 \%$ & $4 \%$ & $2 \%$ & $3 \%$ & $0 \%$ & $0 \%$ & 4.20 \\
\hline
\end{tabular}


Table 4.6 provides a summary of the distribution regarding consumers' willingness to pay a price premium on different stages of the product life cycle. There exists a significant difference between the industry's overall weight distribution and consumers' willingness to pay $(\mathrm{p}<.05)$. Therefore, hypothesis H1b was accepted. Consumers' willingness to pay on apparel industry's different sustainable practices does not match with the industry's perspective, as reflected by the Higg Index.

Table 4.6 Chi-square test result for willingness to pay

\begin{tabular}{cccccccc}
\hline Variables & $\begin{array}{c}\text { Higg } \\
\text { Weights }\end{array}$ & $\begin{array}{c}\text { Estim Prob } \\
\text { (Based on } \\
\text { Higg } \\
\text { weights) }\end{array}$ & $\begin{array}{c}\text { Mean } \\
(\% \\
\text { more) }\end{array}$ & $\begin{array}{c}\text { Hypoth } \\
\text { Prob } \\
\text { (Based on } \\
\text { Mean) }\end{array}$ & $\chi^{\mathbf{2}}$ & DF & p \\
\hline Materials & 25 & 0.294 & 8.268 & 0.232 & 12.88 & 5 & 0.03 \\
Packaging & 7.5 & 0.088 & 4.876 & 0.137 & & \\
Manufacturing & 20 & 0.235 & 6.2 & 0.174 & & \\
Transportation & 7.5 & 0.088 & 4.868 & 0.137 & & \\
Product Care and & 15 & 0.176 & 7.192 & 0.202 & & \\
Repair Service & 10 & 0.118 & 4.202 & 0.118 & & \\
End of Use & 10 & & & & & \\
\hline
\end{tabular}

Results find that consumers are willing to pay the most amount of money on materials with low environmental impacts and they are not willing to pay that much on sustainable practices for the clothing end of use. Previous publications investigating consumer perspective were focused on organic cotton material and indicated that consumers were willing to pay higher price for organic and sustainable cotton materials (Hustvedt \& Bernard, 2008; Ha-Brookshire \& Norum, 2011; Ellis, McCracken \& Skuza, 2012). However, the findings of this study show that consumers are willing to pay an average of $8.3 \%$ more and about $60 \%$ of the consumers are not 
willing to pay more than $10 \%$, which is relatively less than the amount of previous studies. Ellis, McCracken and Skuza (2012) found that consumers were willing to pay $25 \%$ premium for an organic cotton t-shirt. Ha-Brookshire and Norum (2011) revealed that more than half of the consumers were willing to pay about $18 \%$ more on organic $(55.1 \%)$ and sustainable cotton shirts (54.9\%).

Regarding consumers' willingness to pay on sustainable packaging, Young (2008) conducted a cross-cultural study and found that $67 \%$ of the consumers in the U.S., nearly half of the consumers in the UK and Germany, and $23 \%$ of the consumers in China were willing to pay a small amount more on sustainable packaging, equivalent to 5-10 cents more. Additionally, $80 \%$ of the consumers in these four countries agreed that manufacturers should produce environmentally friendly packaging without adding costs to consumers (Young, 2008). The current study finds that consumers are willing to pay nearly $5 \%$ more on average and further supports Young's (2008) publication that consumers are reluctant to pay a lot for sustainable packaging. However, very limited studies have been conducted on consumers' willingness to pay on other sustainable practices. This research provides an insight from a unique angle that compares consumers' willingness to pay on different sustainability practices throughout the product life cycle.

\subsection{Materials}

The survey contained four questions related to materials section. Chi-square goodness-of-fit test was adopted to compare the perspectives of the industry and consumer on materials, and the results are in Table 4.7. There exists a significant difference between the perspectives of the industry and consumers regarding sustainable materials $\left(\mathrm{X}^{2}(3, \mathrm{~N}=250)=10.895, \mathrm{p}<.05\right)$. Hypothesis $\mathrm{H} 2$ was accepted. 
Table 4.7 Chi-square test result for material

\begin{tabular}{|c|c|c|c|c|c|c|c|}
\hline Question & $\begin{array}{l}\text { Higg } \\
\text { Point }\end{array}$ & $\begin{array}{l}\text { Estim } \\
\text { Prob } \\
\text { (Based } \\
\text { on Higg } \\
\text { points) }\end{array}$ & 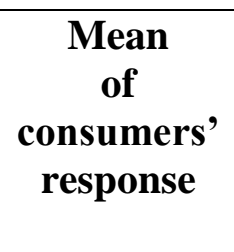 & $\begin{array}{l}\text { Hypoth } \\
\text { Prob } \\
\text { (Based } \\
\text { on } \\
\text { Mean) }\end{array}$ & $\chi^{2}$ & $\begin{array}{l}\text { D } \\
\text { F }\end{array}$ & $\mathbf{p}$ \\
\hline $\begin{array}{l}\text { 4. Track and measure } \\
\text { materials and chemicals } \\
\text { used in the garments }\end{array}$ & 10.5 & 0.259 & 3.604 & 0.227 & 10.90 & 3 & 0.01 \\
\hline $\begin{array}{l}\text { 5. Verify materials does } \\
\text { not contain restricted } \\
\text { substances through } 3^{\text {rd }} \\
\text { party lab testing }\end{array}$ & 15 & 0.370 & 3.744 & 0.236 & & & \\
\hline $\begin{array}{l}\text { 6. Reduce chemical } \\
\text { impacts on environment }\end{array}$ & 7.5 & 0.185 & 3.996 & 0.252 & & & \\
\hline $\begin{array}{l}\text { 7. Can be used for a } \\
\text { longer time }\end{array}$ & 7.5 & 0.185 & 4.540 & 0.286 & & & \\
\hline
\end{tabular}

The Higg Index gives higher points on the companies that track chemicals used in the products and verify garments material does not contain restricted substances. However, consumers give the lowest preference regarding these two practices. One possible reason of this inconsistency might be because most communication of the information regarding restricted substances and chemicals were undergoing between apparel companies and suppliers. Less information about the use of chemicals in products is reaching out to consumers (Fransson \& Molander, 2013). Labeling is one of the ways that consumers can get the information about the products. However, some companies do not use labeling and some are afraid that providing chemical information on some products would convey a signal to consumers that the rest of their products are hazardous (Fransson \& Molander, 2013). The findings of this research are in line with Fransson and Molander's (2013) publication and further 
highlight the importance for apparel companies to communicate and present chemical management information to concerned consumers.

Consumers give the highest purchase preference for the garments whose materials can be used for a longer time. Similarly, a study by Fredriksson and Ytterfors (2015) also indicated that when asking consumers to define the sustainable material, durable materials were the most frequently mentioned by consumers. Several publications also found that consumers preferred durable clothing that can be lasted for a long time (Connell, 2011; Hill \& Lee, 2012). The findings of this study support previous studies that consumers are willing to purchase clothing with enhanced material durability.

\subsection{Packaging}

Four questions in the packaging section were included in the survey. The results of chi-square goodness of fit test to measure if consumers' perspective follows the industry's perspective on packaging are in Table 4.8. There is no significant difference between the perspectives of the industry and consumers $\left(X^{2}(3, N=250)=\right.$ 0.032, $\mathrm{p}=.99$ ). Both the Higg Index and consumers give equal points through Question 9 to Question 12. Therefore, hypothesis H3 was rejected. The points of the Higg Index on packaging can reflect consumer purchase preference.

Table 4.8 Chi-square test result for packaging

\begin{tabular}{|c|c|c|c|c|c|c|c|}
\hline Question & $\begin{array}{l}\text { Higg } \\
\text { Point }\end{array}$ & $\begin{array}{c}\text { Estim } \\
\text { Prob } \\
\text { (Based } \\
\text { on Higg } \\
\text { points) }\end{array}$ & $\begin{array}{c}\begin{array}{c}\text { Mean } \\
\text { of }\end{array} \\
\text { consumers } \\
\text { response }\end{array}$ & $\begin{array}{c}\text { Hypoth } \\
\text { Prob } \\
\text { (Based } \\
\text { on } \\
\text { Mean) }\end{array}$ & $\chi^{2}$ & $\begin{array}{l}\text { D } \\
\text { F }\end{array}$ & $\mathbf{p}$ \\
\hline
\end{tabular}




\begin{tabular}{|c|c|c|c|c|c|}
\hline $\begin{array}{l}\text { 9. Smaller and lighter } \\
\text { packaging while still } \\
\text { protecting the products }\end{array}$ & 4 & 0.25 & 4.084 & 0.23 & $\begin{array}{lll}0.03 & 3 & 0.99\end{array}$ \\
\hline $\begin{array}{l}10 . \text { Track and measure } \\
\text { materials used in } \\
\text { packaging }\end{array}$ & 4 & 0.25 & 3.692 & 0.25 & \\
\hline $\begin{array}{l}\text { 11. Reduce the use of } \\
\text { adhesives, labels, } \\
\text { colorants, inks, etc. in } \\
\text { packaging }\end{array}$ & 4 & 0.25 & 3.880 & 0.26 & \\
\hline $\begin{array}{l}\text { 12. Recyclable } \\
\text { packaging }\end{array}$ & 4 & 0.25 & 4.132 & 0.26 & \\
\hline
\end{tabular}

The findings suggest that consumers share the similar view with the industry that packaging should reduce size and weight, reduce the use of adhesives, labels, colorants and inks as well as use environmentally friendly materials and increase the recyclable components in packaging. Limited research has focused on consumer perception towards apparel packaging. The researcher reviewed packaging for other products and found similar findings. Schwepker and Cornwell (1991) conducted a study on consumer purchase intentions towards ecologically packaged products. They found that consumers were willing to purchase products in less attractive packaging that eliminate unnecessary packaging. Moreover, consumers were in favor of recyclable and biodegradable packaging as well (Schwepker \& Cornwell, 1991). According to a study conducted on food packaging, more than half of the consumers $(66 \%)$ thought that the current packages were too large and the products were over wrapped with too many layers of package (Arvanitoyannis \& Kasaveti, 2008). Another study investigated consumer opinion regarding packaging materials and found that $84 \%$ of the consumers thought the packaging material should be more environmentally friendly (Doyle, 1996). 


\subsection{Manufacturing}

The survey contained five questions in the manufacturing section. The results of chi-square test for comparing the perspectives between the industry and consumers on manufacturing are in Table 4.9. There exists a significant difference between the perspectives of the industry and consumers, $\left(X^{2}(4, N=250)=, p<.05\right)$. Hypothesis H4 was accepted.

Table 4.9 Chi-square test result for manufacturing

\begin{tabular}{|c|c|c|c|c|c|c|c|}
\hline Question & $\begin{array}{l}\text { Higg } \\
\text { Point }\end{array}$ & $\begin{array}{c}\text { Estim } \\
\text { Prob } \\
\text { (Based } \\
\text { on Higg } \\
\text { points) }\end{array}$ & $\begin{array}{c}\begin{array}{c}\text { Mean } \\
\text { of } \\
\text { consumers } \\
\text { response }\end{array} \\
\end{array}$ & $\begin{array}{c}\text { Hypoth } \\
\text { Prob } \\
\text { (Based } \\
\text { on } \\
\text { Mean) }\end{array}$ & $\chi^{2}$ & $\begin{array}{l}\text { D } \\
\text { F }\end{array}$ & $\mathbf{p}$ \\
\hline $\begin{array}{l}\text { 14. Provide manufacturing } \\
\text { suppliers with } \\
\text { environmental guideline }\end{array}$ & 20 & 0.308 & 3.960 & 0.206 & 15.80 & 4 & $<.01$ \\
\hline $\begin{array}{l}15 . \text { Reduce water use in } \\
\text { the manufacturing process }\end{array}$ & 20 & 0.308 & 3.868 & 0.201 & & & \\
\hline $\begin{array}{l}\text { 16. Monitor } \\
\text { manufacturing efficiency } \\
\text { such as textile solid waste } \\
\text { in production }\end{array}$ & 5 & 0.077 & 3.872 & 0.202 & & & \\
\hline $\begin{array}{l}\text { 17. Encourage suppliers to } \\
\text { continuously improve } \\
\text { environmental } \\
\text { performance }\end{array}$ & 15 & 0.231 & 4.044 & 0.211 & & & \\
\hline $\begin{array}{l}\text { 18. Reduce the number of } \\
\text { physical samples }\end{array}$ & 5 & 0.077 & 3.440 & 0.179 & & & \\
\hline
\end{tabular}

The Higg Index gives the highest points on apparel companies that provide suppliers with environmental guidelines and reduce water use in the manufacturing process, whereas giving the lowest points on the companies that monitor 
manufacturing efficiency and reduce sample waste. However, the participants in the current study consider reducing water use and monitoring manufacturing efficiency as equally important manufacturing components. Similarly, Hill and Lee (2012) found that more than half of the participants listed water consumption $(51.3 \%)$ and solid waste $(50.1 \%)$ as the most important environmental issues in the apparel industry. This research supports Hill and Lee's (2012) publication. However, the Higg points on reducing waste water is four times of points on reducing solid waste in production. Given the fact that manufacturing efficiency has great impacts on the environment (Khan \& Islam, 2015) and a total number of $6 \%-25 \%$ of the solid waste were generated in the apparel production process (Ljungberg, 2007), the current research suggests that the Higg Index might reconsider their points distribution during the manufacturing section and gives more attention to solid waste reduction in apparel production.

\subsection{Transportation}

Three questions in the transportation section were selected in survey. Chisquare goodness of fit test was conducted to compare the perspectives between the industry and consumer on transportation, and the results are summarized in Table 4.10. There is no significant difference between the perspectives of the industry and consumers, $\left(\mathrm{X}^{2}(2, \mathrm{~N}=250)=2.819, \mathrm{p}=.24\right)$. Both the Higg Index and consumers have the same point distribution through Question 20 to Question 13. Therefore, hypothesis H5 was accepted. The Higg points on transportation can reflect consumer purchase preference. 
Table 4.10 Chi-square test result for transportation

\begin{tabular}{lccccccc}
\hline \multicolumn{1}{c}{ Question } & $\begin{array}{c}\text { Higg } \\
\text { Point }\end{array}$ & $\begin{array}{c}\text { Estim } \\
\text { Prob } \\
\text { (Based } \\
\text { on Higg } \\
\text { points) }\end{array}$ & $\begin{array}{c}\text { Mean } \\
\text { of } \\
\text { consumers' } \\
\text { response }\end{array}$ & $\begin{array}{c}\text { Hypoth } \\
\text { Prob } \\
\text { (Based } \\
\text { on } \\
\text { Mean) }\end{array}$ & $\chi^{2}$ & $\begin{array}{c}\text { D } \\
\text { F }\end{array}$ & p \\
\hline $\begin{array}{l}\text { 20. Optimize } \\
\text { transportation methods, }\end{array}$ & 30 & 0.429 & 3.756 & 0.334 & 2.82 & 2 & 0.24 \\
$\begin{array}{l}\text { distance, and weight } \\
\begin{array}{l}\text { 1. Maximize the } \\
\text { utilization of } \\
\text { transportation assets }\end{array}\end{array}$ & 20 & 0.286 & 3.736 & 0.332 & & & \\
$\begin{array}{l}\text { 22. Select environmental } \\
\text { friendly carriers }\end{array}$ & 20 & 0.286 & 3.756 & 0.334 & & & \\
\hline
\end{tabular}

The findings suggest that consumers share the similar view with the apparel industry that sustainable transportation should optimize transportation methods, maximize the utilization of cargos and shipping containers, and select sustainable carriers. Similarly, Fredriksson and Ytterfors (2015) conducted a study on comparing consumers and apparel companies view on sustainability in the apparel industry. When interviewed about consumer opinion on the sustainable methods for transports between factories, consumers listed several options, i.e., avoid of freight by air, load the cargos efficiently, and optimize the routes to the clothing distribution outlets. The findings of this study are in line with Fredriksson and Ytterfors's (2015) publication that consumers consider these options as important sustainable methods to reduce the environmental impacts associated with transportation. Consumers do not show preferences on any of these options. 


\subsection{Product Care and Repair Service}

The survey contained four questions related to the product use section. Chisquare goodness of fit test was used to compare the perspectives of the industry and consumer on product care and repair service, and the results are in Table 4.11. There is no significant difference between the perspectives of the industry and consumers, $\left(\mathrm{X}^{2}\right.$ $(3, \mathrm{~N}=250)=1.231, \mathrm{p}=.75)$. Both the Higg Index and consumers have the same point distribution through Question 24 to Question 27. Therefore, hypothesis H6 was accepted. The Higg points can reflect consumer purchase preference.

Table 4.11 Chi-square test result for product care and repair service

\begin{tabular}{lccccccc}
\hline \multicolumn{1}{c}{ Question } & $\begin{array}{c}\text { Higg } \\
\text { Point }\end{array}$ & $\begin{array}{c}\text { Estim } \\
\text { Prob } \\
\text { (Based } \\
\text { on Higg } \\
\text { points) }\end{array}$ & $\begin{array}{c}\text { Mean } \\
\text { of } \\
\text { consumers } \\
\text { response }\end{array}$ & $\begin{array}{c}\text { Hypoth } \\
\text { Prob } \\
\text { (Based } \\
\text { on } \\
\text { Mean) }\end{array}$ & & $\begin{array}{c}\boldsymbol{D}^{2} \\
\text { F }\end{array}$ & $\mathbf{p}$ \\
\hline $\begin{array}{l}\text { 24. Garments that can be } \\
\text { easily repaired }\end{array}$ & 18 & 0.321 & 4.392 & 0.257 & 1.23 & 3 & 0.75 \\
$\begin{array}{l}\text { 25. Enhance garment } \\
\text { durability and longevity }\end{array}$ & 14 & 0.250 & 4.600 & 0.270 & & & \\
$\begin{array}{l}\text { 26. Provide "Product } \\
\text { Care" information }\end{array}$ & 12 & 0.214 & 4.172 & 0.244 & & & \\
$\begin{array}{l}\text { 27. Provide "Repair } \\
\text { Service" information }\end{array}$ & 12 & 0.214 & 3.900 & 0.229 & & & \\
\hline
\end{tabular}

As we can see in Table 4.11, both the Higg Index and consumers give more points on Questions 24 and 25 than Questions 26 and 27. From industry's perspective, they put designing product repairable features and enhancing products' durability and longevity at a higher priority than offering product care and repair guidance to consumers. Similarly, previous literature on consumer studies also found that 
consumers preferred to repair simple tasks such as sewing a button since most consumers have limited sewing skills (Laitala \& Boks, 2012; Norum, 2013; Ryttinger $\&$ Holtmaat, 2014). Furthermore, consumers would repair the clothing which they believed are valuable (Ryttinger \& Holtmaat, 2014). The findings suggest that the apparel industry should select more durable material during the design stage and increase quality control during production since higher quality clothing would motivate consumers to repair and hence improve the clothing longevity (Niinimäki \& Hassi, 2011; Laitala \& Boks, 2012). Moreover, consumers were also highly interested in durable and long-lasting clothing (Hiller, 2011; Hill \& Lee, 2012). Nearly half of the participants in Hill and Lee's (2012) research listed long-lasting garments as the most important environmental issue in the apparel industry. Long-lasting products benefit the environment by preventing consumers frequently discarding and replacing the products (Connell, 2011). Durable and repairable clothing create value for both the industry and consumers. It would not only reduce the environmental impacts for the industry but also bring financial benefits for consumers since they do not need to replace their clothing as often as before (Chen \& Burns 2006).

Regarding product care and repair instructions, the industry view them as less important than other sustainable practices during the product use phase. Previous literature found that $61.4 \%$ of the participants listed "information on laundering and care" the least important sustainable practice during apparel production and utilization (Hill \& Lee, 2012). In addition, not all consumers read about the care labels and many of them were more likely to care for their clothing based on their own experience instead of following the care labels instructions (Laitala \& Klepp, 2013; El-Dessouki, 
2015). This research supports previous studies that consumers do not value the provided clothing care and repair instruction as important sustainable practices.

\subsection{End of Use}

Four questions related to the end of use section were adopted in the survey.

The results of chi-square test for comparing the perspectives between the industry and consumers on end of use are summarized in Table 4.12. Since the Higg Index would give the company 20 points if the company takes any of reuse, repurpose and recycle practices, the researcher combined Question 30 and 31 together to analyze. There exists a significant difference between the perspectives of the industry and consumers, $\left(\mathrm{X}^{2}(2, \mathrm{~N}=250)=9.464, \mathrm{p}<.05\right)$. Hypothesis $\mathrm{H} 7$ was accepted.

Table 4.12 Chi-square test result for end of use

\begin{tabular}{|c|c|c|c|c|c|c|c|}
\hline Question & $\begin{array}{l}\text { Higg } \\
\text { Point }\end{array}$ & $\begin{array}{l}\text { Estim } \\
\text { Prob } \\
\text { (Based } \\
\text { on Higg } \\
\text { points) }\end{array}$ & $\begin{array}{c}\text { Mean } \\
\text { of } \\
\text { consumers' } \\
\text { response }\end{array}$ & $\begin{array}{l}\text { Hypoth } \\
\text { Prob } \\
\text { (Based } \\
\text { on } \\
\text { Mean) }\end{array}$ & $\chi^{2}$ & $\begin{array}{l}\text { D } \\
\text { F }\end{array}$ & $\mathbf{p}$ \\
\hline $\begin{array}{l}\text { 29. Garments that can be } \\
\text { separated for recycling }\end{array}$ & 30 & 0.484 & 3.396 & 0.315 & 9.46 & 3 & $<.01$ \\
\hline $\begin{array}{l}30+31 \text {. Develop } \\
\text { partnerships with charities } \\
\text { or second-hand stores/ } \\
\text { Provide product take-back } \\
\text { service }\end{array}$ & 20 & 0.322 & 3.770 & 0.350 & & & \\
\hline $\begin{array}{l}\text { 32. Provide instructions on } \\
\text { how to deal with garments } \\
\text { after use }\end{array}$ & 12 & 0.193 & 3.616 & 0.335 & & & \\
\hline
\end{tabular}


The Higg Index gives the highest point on Question 29, while consumers give higher preference on Questions 30 and 31, and Question 32. The findings suggest that the industry has been focused a lot on designing products that can be easily separated for recycling. Several publications indicated that the most difficult part for clothing disassembling and further developing into a new product is coming from the diversity of materials (McDonough \& Braungart 2002; Gam, Cao, Bennett, Helmkamp \& Farr, 2011). Minimizing material diversity and sewing similar materials together would help clothing materials compost, recycle, or reuse easier (Gam et al., 2011). Therefore, the apparel industry values whether clothing materials can be easily separated the most. However, from consumers' perspective, they value more about companies' sustainable practices that are related and beneficial to them. Therefore, consumers have a higher purchasing preference on the apparel companies that provide product take-back service or provide instructions on how to dispose clothing in an environmentally friendly way. These findings support the previous study that consumers lacked knowledge of where and how they can dispose their clothing in a sustainable manner (Birtwistle \& Moore, 2007). Furthermore, the results also reflect that apparel companies do not provide enough information on how to deal with garments at the end of their life cycle. In most cases, consumers need to search those information by themselves (Morana \& Seuring, 2007). As cited by one of the participants in the survey:

I was not aware that some products have take-back instructions.

Considering the large amount of post-consumer textile waste sent to the landfills every year (Morgan \& Birtwistle, 2009; Allwood et al., 2006), it is important for apparel companies to publicly communicate clothing after-use instructions with 
consumers through a variety of channels such as websites, advertisement and product packaging, as the Higg Index suggested. 


\section{Chapter 5}

\section{CONCLUSION}

\subsection{Summary of Findings}

The purpose of this study is to investigate consumer acceptance of apparel industry's current sustainable practices and further to find out consumers' willingness to pay a premium on these practices. The apparel industry creates a large amount of environmental impacts throughout the product life cycle including materials, packaging, manufacturing, transportation, product use and end of use (Allwood et al., 2006). The industry's perspective was obtained from the Higg Brand Environmental Module since it is widely accepted by the industry as a criterion on the sustainable performance of apparel and footwear products (Reuben, 2013). Consumers' views in regards to different sustainable practices throughout the product life cycle were established via online survey. All survey questions except questions related to willingness to pay and consumers' demographic information were obtained and rephrased from the Higg Brand Environmental Module. In order to accomplish the three objectives, seven hypotheses were tested in this study and the testing results are presented in Table 5.1.

Table $5.1 \quad$ Results of hypothesis testing

\begin{tabular}{lll}
\hline Objective & \multicolumn{1}{c}{ Hypothesis } & Testing result \\
\hline 1 & $\begin{array}{l}\text { H1a: There exists a significant difference between the } \\
\text { perspectives of the apparel industry and consumers on } \\
\text { the importance of sustainable practices in different }\end{array}$ & H1a accepted \\
\hline
\end{tabular}


stages of the product life cycle.

2 H1b: Consumers' willingness to pay a premium on

H1b accepted apparel industry's sustainable practices in different stages of the product life cycle does not match with the industry's perspective as reflected by the Higg Index $\mathrm{H} 2$ : There exists a significant difference between the perspectives of the apparel industry and consumers on the importance of sustainable practices in materials. H3: There exists a significant difference between the perspectives of the apparel industry and consumers on the importance of sustainable practices in packaging. $\mathrm{H} 4$ : There exists a significant difference between the perspectives of the apparel industry and consumers on the importance of sustainable practices in manufacturing.

H5: There is no significant difference between the perspectives of the apparel industry and consumers on the importance of sustainable practices in transportation. H6: There is no significant difference between the perspectives of the apparel industry and consumers on the importance of sustainable practices in product care and repair service.

H7: There exists a significant difference between the perspectives of the apparel industry and consumers on $\mathrm{H} 2$ accepted

$\mathrm{H} 3$ rejected H4 accepted the importance of sustainable practices in end of use.

The first objective of this research was to identify consumer acceptance of sustainable practices across the product life cycle, including material, manufacturing, packaging, transportation, product care and repair service and end of use. There exists a significant difference between the perspectives of the apparel industry and consumers on the importance of sustainable practices in different stages of the apparel product life cycle. In general, the apparel industry considers materials and manufacturing to be more important, and packaging and transportation less important. This is reflected by Higg Index's higher weight on materials $(25 \%)$ and manufacturing (20\%), and lower weight on packaging (7.5\%) and transportation $(7.5 \%)$, as in Table 
2.1. However, when asked about consumer perception in regards to current sustainable practices in the apparel industry, consumers give their highest purchasing preference towards the product use (care and repair) phase. One possible reason for this is that the product use phase is closely related to consumers. Consumers are pleased to see that apparel companies are making efforts that directly benefit them. Furthermore, the Higg Index ranks manufacturing as the second most important section and apparel companies have been making lots of efforts to minimize the environmental impacts during the apparel production process. However, consumers are less aware of the sustainable practices in the apparel manufacturing. This inconsistency may result from consumers' limited knowledge (Bhaduri \& Ha-Brookshire, 2011; Phau \& Ong, 2007) and limited resources to get the related information. Therefore, apparel companies would benefit if they communicate and educate consumers about how their products are made. Moreover, consumers also value apparel companies' sustainable practices toward packaging. However, the Higg Index only gives packaging very little weight in the overall distribution, suggesting that little attention and efforts were given by the industry. In addition, consumers have the lowest purchasing preference on the sustainable practices regarding the clothing end of use, while the Higg Index put it in the middle position (15\%) in the overall weight distribution. Since consumers' recycling behavior was significantly dependent on convenience (Birtwistle \& Moore, 2007) and they were reluctant to spend too much time or effort towards being environmentally friendly (Laitala, Boks \& Klepp 2011, Gwozdz et al., 2013), apparel companies not only need to educate consumers on the environmental impacts of textile waste and how to dispose their clothing, but also need to provide collection programs to facilitate consumer recycling. 
The second objective of this research was to identify consumers' willingness to pay a premium on sustainable practices across different stages of the product life cycle, including material, manufacturing, packaging, transportation, product care and repair service and end of use. It was found that consumers' willingness to pay for the apparel industry's different sustainable practices does not match with the industry's perspectives as reflected by the Higg Index. Consumers are willing to pay the highest premium on clothing that is made from sustainable materials, and furthermore they would like to pay an average of $8.3 \%$ more for apparel companies' sustainable performance related to materials. Moreover, consumers also highlight that they are willing to pay an average of $7.2 \%$ more for the companies that have adopted sustainable practices in the product use phase. However, consumers are willing to pay the least money for the sustainable efforts related to the clothing end of use.

The third objective of this research was to identify consumer acceptance of sustainable performance within each stage of the product life cycle, including material, manufacturing, packaging, transportation, product care and repair service and end of use. There exists a significant difference between the perspectives of the apparel industry and consumers on the importance of sustainable practices in materials, manufacturing and end of use. Specifically, the apparel industry values material chemical management the most, while consumers consider materials durability as the most important factor in material section. In the apparel manufacturing section, the apparel industry thinks reducing water use is more important than reducing solid waste in production, while consumers view these two practices as equally important manufacturing components. When it comes to the clothing end of use, the apparel industry values designing clothing that can be separated for recycling as more 
important, while consumers are more interested in the sustainable practices that are beneficial to them such as product take-back service or instructions on how to dispose clothing after use. Regarding packaging, transportation, and product care and repair sections, consumers share similar perspectives with the apparel industry on the importance of different sustainable practices, indicating that the Higg Index could reflect consumer perception on these sections.

\subsection{Implications}

Based upon the research findings, several implications can be drawn for the Higg Index and apparel companies. This study aims to provide a better understanding of consumer perception towards apparel companies' current sustainable performance. The findings indicate that the Higg Index needs to reconsider their overall weight distribution and reallocate their resources across different stages of the product life cycle accordingly. It is recommended to increase the weights of packaging and produce care and repair service, and to reduce the weights of manufacturing and end of use in the overall distribution. The Higg Index is suggested to pay more attention and effort towards reducing packaging waste and to make more effort towards the sustainable practices related to the product use phase, which directly benefits consumers.

Within each stage of the product life cycle, it is suggested to reconsider and revise the point allocation in Higg Index's materials, manufacturing and end of use sections. In the materials stage, the Higg Index may increase the points of material durability and reduce the points related to material chemical management. In the manufacturing stage, the Higg Index may increase the points of solid waste reduction and further take energy consumption and chemical use into consideration when 
allocating the points. In the clothing end of use stage, the Higg Index may increase the points for the companies that have provided product take-back service and have provided clothing after-use instructions. Taking consumers into consideration while allocating the distribution would narrow the gap of the perspectives of the industry and consumers, and further motivate consumers to accept environmentally friendly apparel products.

This research gives the apparel industry an opportunity to reach out to the general consumer and have their voice heard. With a better understanding of consumer perception, the apparel industry would be able to improve and revise their current sustainable performance. In return, these actions would further motivate consumers to purchase environmentally friendly apparel products in the long term. In addition, apparel companies are suggested to communicate their sustainability-related performance to consumers in order to promote transparency of the supply chains as well as to facilitate consumers' engagement. Apparel companies are also encouraged to educate consumers about the environmental knowledge at each stage throughout the clothing life cycle. Increasing consumers' knowledge of sustainability, and further increasing consumer acceptance on environmentally friendly apparel products need the collaboration among apparel companies, government, NGOs and other organizations.

\subsection{Limitations and Future Research}

This study has some limitations and recommendations for future research are offered. First, the sample size of this study was relatively small $(n=250)$ and was limited to the U.S. consumers. The Sustainable Apparel Coalition (SAC) is a global organization and its members are companies from fashion, manufacturing and retailing 
all over the world. Therefore, future research is encouraged to use a larger population and further investigate consumer perspectives in different countries. Second, this research used the Higg Brand Environmental Module to represent industry's perspective on the importance of different sustainable practices. Future research may further survey apparel companies' professionals such as sustainability manager in order to have a more comprehensive understanding. Third, this study used the participants as a whole to analyze consumer perceptions. Future research could further investigate the relationship between demographic factors such as gender, age, education and household income and consumer perception of sustainable practices in different stages of the product life cycle. Fourth, this study used quantitative research and most questions in the online survey were based on the Higg Brand Environmental Module. Future research in this field could incorporate qualitative methods such as focus group interview and gain an in-depth picture of consumer perception in the U.S., as well as in other countries. 


\section{REFERENCES}

1. Allwood, J. M., Laursen, S. E., de Rodriguez, C. M., \& Bocken, N. M. (2006). Well dressed?: The present and future sustainability of clothing and textiles in the United Kingdom. Cambridge, UK: University of Cambridge, Institute for Manufacturing.

2. American Apparel \& Footwear Association (2013). Restricted Substances List $\left(12^{\text {th }}\right.$ Ed.). Retrieved from https://www.wewear.org/assets/1/7/RSL12english-March2013.pdf.

3. American Apparel \& Footwear Association (2015). ApparelStats 2014 and ShoeStats 2014 Reports. Retrieved from https://www.wewear.org/apparelstats-2014-and-shoestats-2014-reports.

4. Arvanitoyannis, I. S., \& Kasaveti, A. (2008). Consumer attitude to food packaging and the market for environmentally compatible products. In E. Chiellini (Ed.), Environmentally compatible food packaging (pp. 161-181). Cambridge, UK: Woodhead Publishing.

5. Badore, M. (2015, March 17). Levi's wants you to help lower the impact of jeans. Retrieved from http://www.treehugger.com/corporateresponsibility/levis-wants-you-help-lower-impact-jeans.html.

6. Bai, C., \& Sarkis, J. (2010). Integrating sustainability into supplier selection with grey system and rough set methodologies. International Journal of Production Economics, 124(1), 252-264.

7. Bamberg, S. (2003). How does environmental concern influence specific environmentally related behaviors? A new answer to an old question. Journal of environmental psychology, 23(1), 21-32.

8. Becker, T. (2014, April 4). Worn wear: Initiative for sustainability by Patagonia. Retrieved from http://www.ispo.com/en/companies/id_77743408/worn-wear-initiative-forsustainability-by-patagonia.html. 
9. Bhaduri, G., \& Ha-Brookshire, J. E. (2011). Do transparent business practices pay? Exploration of transparency and consumer purchase intention. Clothing and Textiles Research Journal, 29(2), 135-149.

10. Birtwistle, G., \& Moore, C. M. (2007). Fashion clothing-where does it all end up? International Journal of Retail \& Distribution Management, 35(3), 210-216.

11. Boström, M., Börjeson, N., Gilek, M., Jönsson, A. M., \& Karlsson, M. (2011). Towards responsible procurement in relation to chemical risks in textiles? Findings from an interview study. Retrieved from https://www.diva-portal.org/smash/get/diva2:404864/FULLTEXT01.pdf.

12. Brosdahl, D. J., \& Carpenter, J. M. (2010). Consumer knowledge of the environmental impacts of textile and apparel production, concern for the environment, and environmentally friendly consumption behavior. Journal of Textile and Apparel, Technology And Management, 6(4).

13. Burns, L. D., \& Bryant, N. O. (2002). The business of fashion: Designing, manufacturing, and marketing ( $2^{\text {nd }}$ ed.). New York, NY: Fairchild Publications.

14. Caniato, F., Caridi, M., Crippa, L., \& Moretto, A. (2012). Environmental sustainability in fashion supply chains: An exploratory case based research. International journal of production economics, 135(2), 659-670.

15. Cao, H., Dickson, M. A., Cobb, K., Carper, M., Scudder, C., \& Wong, C. (2015). Applying a sustainability performance measurement tool in designing and developing automotive employee uniforms. International Journal of Fashion Design, Technology and Education, 8(2), 78-86.

16. Chan, T. Y., \& Wong, C. W. (2012). The consumption side of sustainable fashion supply chain: Understanding fashion consumer eco-fashion consumption decision. Journal of Fashion Marketing and Management: An International Journal, 16(2), 193-215.

17. Chang, Y., Chen, H. L., \& Francis, S. (1999). Market applications for recycled postconsumer fibers. Family and consumer sciences research journal, 27(3), 320-340. 
18. Chapman, A. (2010). Mistra future fashion-Review of life cycle assessment. Stockholm, Sweden: MISTRA — The Foundation for Strategic Environmental Research. Retrieved from http://www.oakdenehollins.co.uk/media/232/2010_mistra_review_of_life_ cycle_assessments_of_clothing.pdf.

19. Chen, H. L., \& Burns, L. D. (2006). Environmental analysis of textile products. Clothing and Textiles Research Journal, 24(3), 248-261.

20. Chen, C., \& Lewis, V. D. (2005, November). The life of a piece of cloth: developing garments into a sustainable service system. In proceedings of International Textile \& Apparel Association, Inc., ITAA, Alexandria, VA, 62, 662-667.

21. Connell, K. Y. (2011). Exploring consumers' perceptions of eco-conscious apparel acquisition behaviors. Social Responsibility Journal, 7(1), 61-73.

22. Connell, K. Y., \& Kozar, J. M. (2012). Social normative influence: An exploratory study investigating its effectiveness in increasing engagement in sustainable apparel-purchasing behaviors. Journal of Global Fashion Marketing, 3(4), 172-179.

23. Cooper, T., Fisher, T., Hiller, A., Goworek, H., \& Woodward, S. (2010). Excessive speed/short lives - Attitudes to clothing longevity and disposal. In F. Ceschin, C. Vezzoli \& J. Zhang (Eds.), In Proceedings of the LeNS conference Sustainability in design: NOW, Bangalore, India, 29 September - 1 October (pp. 728-737).

24. Dembkowski, S. (1998). The environmental value-attitude-system model understanding the divergence between stated environmental consciousness and overt consumer behaviour. Eco-Management and Auditing, 5(2), 6274.

25. Doyle, M. (1996). The consumer side of packaging power. In M. Doyle (Ed.), Packaging strategy: Winning the consumer (pp.153-176). Boca Raton, FL: CRC Press.

26. El-Dessouki, H. A. (2015). A survey on knowledge about care label on garments by Residents in Egypt. Life Science Journal, 12(3s), 49-53.

27. Ellis, J. L., McCracken, V. A., \& Skuza, N. (2012). Insights into willingness to pay for organic cotton apparel. Journal of Fashion Marketing and Management: An International Journal, 16(3), 290-305. 
28. Environmental Protection Agency (2013). Retrieved from http://www3.epa.gov/epawaste/wastes_archive/textiles.htm.

29. Fisher, T., Cooper, T., Woodward, S., Hiller, A., \& Goworek, H. (2008). Public understanding of sustainable clothing: a report to the Department for Environment, Food and Rural Affairs. London, UK: Department for Environment, Food and Rural Affairs.

30. Fletcher, K. (2008). Sustainable fashion and textiles. London, UK: Earthscan.

31. Fletcher, K. (2010). Slow fashion: An invitation for systems change. Fashion Practice, 2(2), 259-265.

32. Fransson, K., \& Molander, S. (2013). Handling chemical risk information in international textile supply chains. Journal of Environmental Planning and Management, 56(3), 345-361.

33. Fredriksson, M., \& Ytterfors, M. (2015). Defining sustainability: a consumer versus company view in the Swedish apparel industry. Unpublished master thesis, The Swedish School of Textiles, University of Borås, Borås, Sweden.

34. Fulton, K., \& Lee, S. E. (2010). An overview of sustainability in the fashion industry. International Journal of Environmental, Cultural, Economic and Social Sustainability, 6(1), 1-14.

35. Fulton, K., \& Lee, S. E. (2013). Assessing sustainable initiatives of apparel retailers on the internet. Journal of Fashion Marketing and Management: An International Journal, 17(3), 353-366.

36. Gam, H. J., Cao, H., Bennett, J., Helmkamp, C., \& Farr, C. (2011). Application of design for disassembly in men's jacket: A study on sustainable apparel design. International Journal of Clothing Science and Technology, 23(2/3), 83-94.

37. Gam, H. J., Cao, H., Farr, C., \& Kang, M. (2010). Quest for the ecoapparel market: a study of mothers' willingness to purchase organic cotton clothing for their children. International Journal of Consumer Studies, 34(6), 648-656.

38. Goworek, H. (2011). Social and environmental sustainability in the clothing industry: a case study of a fair trade retailer. Social Responsibility Journal, 7(1), 74-86. 
39. Goworek, H., Fisher, T., Cooper, T., Woodward, S., \& Hiller, A. (2012). The sustainable clothing market: an evaluation of potential strategies for UK retailers. International journal of retail \& distribution management, 40(12), 935-955.

40. Göritz, A. S. (2006). Incentives in web studies: Methodological issues and a review. International Journal of Internet Science, 1(1), 58-70.

41. Hanss, D., \& Böhm, G. (2012). Sustainability seen from the perspective of consumers. International Journal of Consumer Studies, 36(6), 678-687.

42. Ha-Brookshire, J. E., \& Norum, P. S. (2011). Willingness to pay for socially responsible products: case of cotton apparel. Journal of Consumer Marketing, 28(5), 344-353.

43. Hartman Group (2007), The fiber of organics. Retrieved from www.hartman-group.com/hartbeat/ the-fiber-of-organics.

44. Hawley, J. M. (2006). Digging for diamonds: A conceptual framework for understanding reclaimed textile products. Clothing and Textiles Research Journal, 24(3), 262-275.

45. Hill, J., \& Lee, H. H. (2012). Young generation Y consumers' perceptions of sustainability in the apparel industry. Journal of Fashion Marketing and Management: An International Journal, 16(4), 477-491.

46. Hines, J. D., \& Swinker, M. E. (1996). Consumers' willingness to purchase apparel produced from recycled fibers. Journal of family and consumer sciences (USA), 88(4), 41-44.

47. Hustvedt, G., \& Bernard, J. C. (2008). Consumer willingness to pay for sustainable apparel: The influence of labelling for fibre origin and production methods. International Journal of Consumer Studies, 32(5), 491-498.

48. Information Research Institute (2007). Consumer-focused CPG growth opportunity. Retrieved from http://us.infores.com/Insights/Publications/TimesTrends/tabid/106/currentp age/4/Default.aspx.

49. Jacoby, J., Berning, C. K., \& Dietvorst, T. F. (1977). What about disposition?. Journal of Marketing, 41(2), 22-28. 
50. Kang, J., Liu, C., \& Kim, S. H. (2013). Environmentally sustainable textile and apparel consumption: the role of consumer knowledge, perceived consumer effectiveness and perceived personal relevance. International Journal of Consumer Studies, 37(4), 442-452.

51. Khan, M. M. R., \& Islam, M. M. (2015). Materials and manufacturing environmental sustainability evaluation of apparel product: knitted T-shirt case study. Textiles and Clothing Sustainability, 1(1), 1-12.

52. Kim, F. (2010, April 21). Green day. Women's Wear Daily, 195(2), 6.

53. Kirchain, R., Olivetti, E., Miller, T. R., \& Greene, S. (2015). Sustainable apparel materials. Retrieved from http://msl.mit.edu/publications/SustainableApparelMaterials.pdf.

54. Klepp, I. G. (2001). Hvorfor går klær ut av bruk. Avhending sett i forhold til kvinners klesvaner.

55. Koenig, R. (2015, December 1). Goodwill makes it easy for shoppers to donate goods by mail - for free. The Chronicle of Philanthropy. Retrieved from https://philanthropy.com/article/Goodwill-Makes-It-Easy-for/234405.

56. Kozar, J. M., \& Connell, K. Y. H. (2015). Measuring and communication apparel sustainability. In R. Blackburn (Ed.), Sustainable Apparel: Production, Processing and Recycling (pp. 219-231). Cambridge, UK: Woodhead Publishing.

57. Kruschwitz, A., Karle, A., Schmitz, A., \& Stamminger, R. (2014). Consumer laundry practices in Germany. International Journal of Consumer Studies, 38(3), 265-277.

58. Laitala, K., \& Boks, C. (2012). Sustainable clothing design: use matters. Journal of Design Research 14, 10(1-2), 121-139.

59. Laitala, K., Boks, C., \& Klepp, I. G. (2011). Potential for environmental improvements in laundering. International Journal of Consumer Studies, 35(2), 254-264.

60. Laitala, K., \& Klepp, I. G. (2011). Environmental improvement by prolonging clothing use period. Towards sustainability in the textile and fashion industry, 26, 2011. 
61. Laitala, K., \& Klepp, I. G. (2013). Environmental and ethical perceptions related to clothing labels among Norwegian consumers. Textile and Apparel Research Journal of Textile and Apparel, 17(1), 50-58.

62. Laitala, K., Klepp, I. G., \& Boks, C. (2012). Changing laundry habits in Norway. International Journal of Consumer Studies, 36(2), 228-237.

63. Lin, S. H. (2010). A case study in Hawaii: who will pay more for organic cotton?. International Journal of Consumer Studies, 34(4), 481-489.

64. Ljungberg, L. Y. (2007). Materials selection and design for development of sustainable products. Materials \& Design, 28(2), 466-479.

65. Liecke, A.D. (2015, June 17). This sweatshirt will last 30 years, guaranteed. Retrieved from http://www.esquire.com/style/mensfashion/news/a35775/the-30-year-sweatshirt/.

66. Luz, C. (2007). Waste couture: Environmental impact of the clothing industry. Environmental Health Perspectives, 115(9), A448.

67. Martinho, G., Pires, A., Portela, G., \& Fonseca, M. (2015). Factors affecting consumers' choices concerning sustainable packaging during product purchase and recycling. Resources, Conservation and Recycling, $103,58-68$.

68. Mason, W., \& Suri, S. (2012). Conducting behavioral research on Amazon's Mechanical Turk. Behavior research methods, 44(1), 1-23.

69. McDonough, W., \& Braungart, M. (2002). Design for the triple top line: new tools for sustainable commerce. Corporate Environmental Strategy, 9(3), 251-258.

70. Meyer, A. (2001). What's in it for the customers? Successfully marketing green clothes. Business Strategy and the Environment, 10(5), 317-330.

71. Michon, R., Yu, H., Smith, D., \& Chebat, J. C. (2008). The influence of mall environment on female fashion shoppers' value and behaviour. Journal of Fashion Marketing and Management: An International Journal, 12(4), 456-468.

72. Moon, K. K. L., Youn, C., Chang, J. M., \& Yeung, A. W. H. (2013). Product design scenarios for energy saving: A case study of fashion apparel. International Journal of Production Economics, 146(2), 392-401. 
73. Morana, R., \& Seuring, S. (2007). End-of-life returns of long-lived products from end customer-insights from an ideally set up closed-loop supply chain. International Journal of Production Research, 45(18-19), 4423-4437.

74. Morgan, L. R., \& Birtwistle, G. (2009). An investigation of young fashion consumers' disposal habits. International Journal of Consumer Studies, 33(2), 190-198.

75. Muthu, S. S., Li, Y., Hu, J. Y., \& Mok, P. Y. (2009). An exploratory comparative study on eco-impact of paper and plastic bags. Journal of Fiber Bioengineering and Informatics, 1(4), 307-320.

76. Niinimäki, K., \& Hassi, L. (2011). Emerging design strategies in sustainable production and consumption of textiles and clothing. Journal of Cleaner Production, 19(16), 1876-1883.

77. Nike Flyknit: Waste reduced by two million pounds in weight so far. (2015, April 1). Innovation in Textiles. Retrieved from http://www.innovationintextiles.com/nike-flyknit-waste-reduced-by-twomillion-pounds-in-weight-so-far/.

78. Nordin, N., \& Selke, S. (2010). Social aspect of sustainable packaging. Packaging Technology and Science, 23(6), 317-326.

79. Norum, P. S. (2013). Examination of Apparel Maintenance Skills and Practices: Implications for Sustainable Clothing Consumption. Family and Consumer Sciences Research Journal, 42(2), 124-137.

80. Nunnally, J.C. (1967). Psychometric Theory. New York, NY: McGrawHill.

81. Oxfam (2012). M\&S clothes exchange. Retrieved from http://www.oxfam.org.uk/donate/donate-goods/mands-and-oxfamshwopping.

82. Phau, I., \& Ong, D. (2007). An investigation of the effects of environmental claims in promotional messages for clothing brands. Marketing Intelligence \& Planning, 25(7), 772-788.

83. Reuben, A. (2013). The Higg index for sustainable apparel environmental performance index. Retrieved from http://epi.yale.edu/epi2012/casestudies/reports/higg-index-sustainableapparel. 
84. Ritch, E., Brennan, C., \& MacLeod, C. (2009). Plastic bag politics: modifying consumer behaviour for sustainable development. International Journal of Consumer Studies, 33(2), 168-174.

85. Romano, K. (2012, November 14). Will Green-Friendly "Bluesign" Clothing Lines Catch On with Consumers? Scientific American. Retrieved from http://www.scientificamerican.com/article/green-friendly-bluesignclothing/.

86. Ryttinger, L., \& Holtmaat, K. (2014). The work on sustainability in the use and disposal stage of a garment's life cycle - The perspective of three Swedish clothing companies. Unpublished master's thesis, The Swedish School of Textiles, University of Borås, Borås, Sweden. Retrieved from http://bada.hb.se/bitstream/2320/14239/1/2014.7.02.pdf.

87. Schwepker Jr, C. H., \& Cornwell, T. B. (1991). An examination of ecologically concerned consumers and their intention to purchase ecologically packaged products. Journal of Public Policy \& Marketing, 77101.

88. Scott, L., \& Vigar-Ellis, D. (2014). Consumer understanding, perceptions and behaviours with regard to environmentally friendly packaging in a developing nation. International Journal of Consumer Studies, 38(6), 642649.

89. Scruggs, C. E. (2013). Reducing hazardous chemicals in consumer products: proactive company strategies. Journal of Cleaner Production, 44, 105-114.

90. Subic, A., Shabani, B., Hedayati, M., \& Crossin, E. (2012). Capability framework for sustainable manufacturing of sports apparel and footwear.Sustainability, 4(9), 2127-2145.

91. Thøgersen, J. (2000). Psychological determinants of paying attention to eco-labels in purchase decisions: Model development and multinational validation. Journal of Consumer Policy, 23(3), 285-313.

92. United States Census Bureau (2014). Retrieved from https://www.census.gov/quickfacts/table/EDU685214/00.

93. University of Delaware Sustainable Apparel Initiative (2009). Creating a more environmentally sustainable apparel business: policies for apparel brands and retailers. Newark, DE: University of Delaware Sustainable Apparel Initiative. 
94. Vestel, L. B. (2009, October 27). With New Care Tags, Levi Strauss Aims to Reduce Its Footprint. The New York Times. Retrieved from http://green.blogs.nytimes.com/2009/10/27/with-new-consumer-care-tagslevi-strauss-aims-to-reduce-its-carbon-footprint/?_r=0.

95. Walker, L. (2012, April 13). H\&M Sustainability Report: CO2 Emissions Drop 5\% in 2011. Environmental and Energy Management News. Retrieved from http://www.environmentalleader.com/2012/04/13/hmsustainability-report-co2-emissions-drop-5-in-2011/.

96. Yeung, A. H. W., \& Yeung, P. K. W. (2011). Bridging the sustainability gap in the global fashion supply chain-Role of the sustainable fashion business consortium. In Proceedings of the 11th Asian textile conference on knowledge convergence in textiles for human \& nature (pp. 1266-1269).

97. Young, S. (2007). Sustainable packaging: the shopper's perspective. Brand Packaging, 11(3), 14-16.

98. Young, S. (2008). Packaging and the Environment: A Cross-Cultural Perspective. Design Management Review, 19(4), 42-48. 


\section{Appendix A}

\section{IRB REVIEW AND CONSENT FORM}

You are invited to participate in a research study. This consent form tells you about the study including its purpose, what you will be asked to do if you decide to take part, and the risks and benefits of being in the study. Please read the information below and ask us any questions you may have before you decide whether or not you agree to participate.

The purpose of this study is to investigate consumers' perspectives in regards to environmentally friendly fashion products and whether or not willing to pay a price premium for sustainable apparel practices. Participation should require approximately 15 minutes of your time. Participation is entirely voluntary; you may withdraw from the study at any time without consequences. All participants are required to be US based and 18 years of age or older.

The survey will be conducted with Qualtrics (http://www.qualtrics.com), an online survey software. There will be no time limit. The session will go for up to 20 minutes, or as needed. The survey will be conducted on an individual basis and will not require any further participation once you have completed the survey. There are no risks involved with this study. During the survey you may choose to stop participating at any time.

Your responses will be anonymous; data will be analyzed and reported in aggregate form. We request general demographic information to help with our 
analysis but it will not be used to identify the source of responses. All records will be kept in a locked file cabinet in the secured research place provided to the faculty advisor for at least 5 years or until all related projects are completed, after which these paper records will be destroyed by a paper shredder.

There is some compensation available for participating in this study. You will be paid $\$ 1.00$ for carefully and completely responding to the questionnaire in this research project. You can participate in this study only once and will not be compensated a second time.

If you have any questions, please contact Xingqiu Lou (leonalou@udel.edu). If you have questions regarding your rights as a participant, you may contact the Chair of the Human Subjects Review Board at hsrb-research@udel.edu or (302) 831-2137.

To participate in this study you must be 18 years of age or older If you consent to participating in this study, click on the link below. 


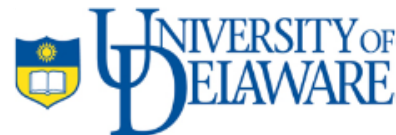

DATE:

TO:

FROM:

STUDY TITLE:

SUBMISSION TYPE:

ACTION:

DECISION DATE:

REVIEW CATEGORY:
April 11, 2016

Xingqiu Lou

University of Delaware IRB

[886000-2] Consumers' preference of environmentally friendly fashion

products

Amendment/Modification

DETERMINATION OF EXEMPT STATUS

April 11, 2016

Exemption category \# (2)

Thank you for your submission of Amendment/Modification materials for this research study. The University of Delaware IRB has determined this project is EXEMPT FROM IRB REVIEW according to federal regulations.

We will put a copy of this correspondence on file in our office. Please remember to notify us if you make any substantial changes to the project.

If you have any questions, please contact Nicole Farnese-McFarlane at (302) 831-1119 or nicolefm@udel.edu. Please include your study title and reference number in all correspondence with this office. 


\section{Appendix B}

\section{SURVEY QUESTIONNAIRE}

Directions: Using the 5-point scale below, please select the choice that best matches your feelings for each of the statement.

1. I have sufficient knowledge about apparel products.

$\square$ Strongly disagree

$\square$ Disagree

$\square$ Neutral

$\square$ Agree

$\square$ Strongly agree

2. I have sufficient knowledge about environmental impacts related to apparel production and utilization.

$\square$ Strongly disagree

$\square$ Disagree

$\square$ Neutral

$\square$ Agree

$\square$ Strongly agree

Material

3. Please rank the following material in terms of environmental impact, from the least (No.1) to the most (No.7) environmental friendly.
$\square$ Cotton
$\square$ Wool
$\square$ Silk
$\square$ Polyester Fabric
$\square$ Nylon
$\square$ Rayon
$\square$ Flex/Linen

4. When other factors remain the same, I prefer to purchase garments from the fashion companies which track and measure materials and chemicals used in the garments. 
$\square$ Strongly disagree

$\square$ Disagree

$\square$ Neutral

$\square$ Agree

$\square$ Strongly agree

5. When other factors remain the same, I prefer to purchase garments from the fashion companies which require their suppliers to verify not containing restricted substances through independent, $3^{\text {rd }}$ party lab testing.

$\square$ Strongly disagree

$\square$ Disagree

$\square$ Neutral

$\square$ Agree

$\square$ Strongly agree

6. When other factors remain the same, I prefer to purchase garments whose materials reduce chemical impacts on environment. (e.g., organic cotton with reduced pesticide use; Avoid using hazardous chemicals in production.)

$\square$ Strongly disagree

$\square$ Disagree

$\square$ Neutral

$\square$ Agree

$\square$ Strongly agree

7. When other factors remain the same, I prefer to purchase garments materials that can be used a longer time.

$\square$ Strongly disagree

$\square$ Disagree

$\square$ Neutral

$\square$ Agree

$\square$ Strongly agree

8. How much more are you willing to pay for the garments made from materials with low environmental impact?

$\square 0$

$\square 1-5 \%$

$\square 6-10 \%$

$\square 11-15 \%$

$\square 16-20 \%$

$\square 21-25 \%$

$\square 26-30 \%$

$\square$ Other (Pease specify) 


\section{Packaging}

9. When other factors remain the same, I prefer to purchase garments with smaller and lighter packaging while still protecting the products in transportation and retailing.

$\square$ Strongly disagree

$\square$ Disagree

$\square$ Neutral

$\square$ Agree

$\square$ Strongly agree

10. When other factors remain the same, I prefer to purchase garments from companies which track and measure materials used in packaging.

$\square$ Strongly disagree

$\square$ Disagree

$\square$ Neutral

$\square$ Agree

$\square$ Strongly agree

11. When other factors remain the same, I prefer to purchase garments with the reduce use of adhesives, labels, colorants, inks, etc. in packaging.

$\square$ Strongly disagree

$\square$ Disagree

$\square$ Neutral

$\square$ Agree

$\square$ Strongly agree

12. When other factors remain the same, I prefer to purchase garments with a recyclable packaging.

$\square$ Strongly disagree

$\square$ Disagree

$\square$ Neutral

$\square$ Agree

$\square$ Strongly agree

13. How much more are you willing to pay for sustainable packaging (e.g., recyclable packaging, using recycled materials, reducing adhesive/label use)?
$\square 0$
$\square 1-5 \%$
$\square 6-10 \%$
$\square 11-15 \%$
16-20\%
$21-25 \%$
口 26-30\% 
$\square$ Other (Pease specify)

Manufacturing

14. When other factors remain the same, I prefer to purchase garments from the fashion companies that provide manufacturing suppliers with environmental guideline such as legal requirements, best practice examples, environmental management system.

$\square$ Strongly disagree

$\square$ Disagree

$\square$ Neutral

$\square$ Agree

$\square$ Strongly agree

15. When other factors remain the same, I prefer to purchase garments from the fashion companies that reduce water use in its manufacturing process.

$\square$ Strongly disagree

$\square$ Disagree

$\square$ Neutral

$\square$ Agree

$\square$ Strongly agree

16. When other factors remain the same, I prefer to purchase garments from the fashion companies that monitor manufacturing efficiency such as textile solid waste in production.

$\square$ Strongly disagree

$\square$ Disagree

$\square$ Neutral

$\square$ Agree

$\square$ Strongly agree

17. When other factors remain the same, I prefer to purchase garments from the fashion companies that encourage its suppliers to continuously improve their environmental performance. (Such as reduced water use, energy use and solid waste)

$\square$ Strongly disagree

$\square$ Disagree

$\square$ Neutral

$\square$ Agree

$\square$ Strongly agree

18. When other factors remain the same, I prefer to purchase garments from the fashion companies that reduce the number of physical samples used in product development process. 
$\square$ Strongly disagree

$\square$ Disagree

$\square$ Neutral

$\square$ Agree

$\square$ Strongly agree

19. How much more are you willing to pay for the garments with low environmental impact in manufacturing?

$\square 0$

$\square 1-5 \%$

$\square 6-10 \%$

$\square 11-15 \%$

$\square 16-20 \%$

$\square 21-25 \%$

$\square 26-30 \%$

$\square$ Other (Pease specify)

Transportation

20. When other factors remain the same, I prefer to purchase garments from the fashion companies that optimize transportation methods (airplane, train, truck or ship), distance, and weight.

$\square$ Strongly disagree

$\square$ Disagree

$\square$ Neutral

$\square$ Agree

$\square$ Strongly agree

21. When other factors remain the same, I prefer to purchase garments from the fashion companies that maximize the utilization of transportation assets (e.g., efficiently loading the cargos using 20 feet container instead of a half empty 40 feet container).

$\square$ Strongly disagree

$\square$ Disagree

$\square$ Neutral

$\square$ Agree

$\square$ Strongly agree

22. When other factors remain the same, I prefer to purchase garments from the fashion companies that select environmental friendly carriers based on annual emission reports.

$\square$ Strongly disagree

$\square$ Disagree

$\square$ Neutral 
$\square$ Agree

$\square$ Strongly agree

23. How much more are you willing to pay for sustainable transportation (e.g., avoiding air freight transportation since it is the highest contributor on Greenhouse Gas emission)?

$\square 0$

$\square 1-5 \%$

$\square 6-10 \%$

$\square 11-15 \%$

$\square 16-20 \%$

$\square 21-25 \%$

$\square 26-30 \%$

$\square$ Other (Pease specify)

Product Care and Repair Service

24. When other factors remain the same, I prefer to purchase garments that can be easily repaired (e.g., replacement buckles, zipper pulls, components, and accessories).

$\square$ Strongly disagree

$\square$ Disagree

$\square$ Neutral

$\square$ Agree

$\square$ Strongly agree

25. When other factors remain the same, I prefer to purchase garments with enhanced durability and longevity.

$\square$ Strongly disagree

$\square$ Disagree

$\square$ Neutral

$\square$ Agree

$\square$ Strongly agree

26. When other factors remain the same, I prefer to purchase garments that provide "Product Care" information such as low impact care instructions.

$\square$ Strongly disagree

$\square$ Disagree

$\square$ Neutral

$\square$ Agree

$\square$ Strongly agree

27. When other factors remain the same, I prefer to purchase garments that provide "Repair Service" information such as repair and replace guidance. 
$\square$ Strongly disagree

$\square$ Disagree

$\square$ Neutral

$\square$ Agree

$\square$ Strongly agree

28. How much more are you willing to pay for fashion companies' sustainable practices related to product care and repair service?

$\square 0$

$\square 1-5 \%$

$\square 6-10 \%$

$\square 11-15 \%$

$\square 16-20 \%$

$\square 21-25 \%$

$\square 26-30 \%$

$\square$ Other (Pease specify)

End of Use

29. When other factors remain the same, I prefer to purchase garments that can be separated for recycling (e.g., separate textile fabric and metal zipper).

$\square$ Strongly disagree

$\square$ Disagree

$\square$ Neutral

$\square$ Agree

$\square$ Strongly agree

30. When other factors remain the same, I prefer to purchase garments from the fashion companies that develop partnerships with charities or second-hand stores.

$\square$ Strongly disagree

$\square$ Disagree

$\square$ Neutral

$\square$ Agree

$\square$ Strongly agree

31. When other factors remain the same, I prefer to purchase garments from the fashion companies that have product take-back service.

$\square$ Strongly disagree

$\square$ Disagree

$\square$ Neutral

$\square$ Agree

$\square$ Strongly agree 
32. When other factors remain the same, I prefer to purchase garments from the fashion companies that provide instructions on how to deal with garments after use.

$\square$ Strongly disagree

$\square$ Disagree

$\square$ Neutral

$\square$ Agree

$\square$ Strongly agree

33. How much more are you willing to pay for fashion companies' sustainable practices (e.g., reuse, recycling, donate to charities) related to product end of use? $\square 0$

$\square 1-5 \%$

$\square 6-10 \%$

$\square 11-15 \%$

$\square 16-20 \%$

$\square 21-25 \%$

$\square$ 26-30\%

$\square$ Other (Pease specify)

Demographic Questions

34. What is your gender?

$\square$ Female

$\square$ Male

$\square$ Other

35. What is your age?
$\square$ 18-24 years
$\square$ 25-34 years
$\square$ 35-44 years
$\square$ 45-54 years
$\square$ 55-64 years
$\square 65$ years or older

36. Which race/ethnicity best describes you?

$\square$ African American/Black

$\square$ Asian/Pacific Islander

$\square$ Hispanic/Latino

$\square$ Multiracial

$\square$ Native American/American Indian

$\square$ White

$\square$ Not Listed (please specify) 
37. What is your highest achieved education level?

$\square$ Less than high school

$\square$ High School or equivalency

$\square$ Bachelor's degree

$\square$ Master's degree

$\square$ Beyond master's degree

38. What is your annually household income before taxes?
$\square$ Less than $\$ 25,000$
$\square \$ 25,000$ to $\$ 34,999$
$\square \$ 35,000$ to $\$ 49,999$
$\square \$ 50,000$ to $\$ 74,999$
$\square \$ 75,000$ to $\$ 99,999$
$\square \$ 100,000$ to $\$ 149,999$
$\square \$ 150,000$ or more

Please add your comments:

Thank you for your time! 